\title{
Mudança e Teoria Ator-Rede: Humanos e Não Humanos em Controvérsias na Implementação de um Centro de Serviços Compartilhados
}

Clovis Cerretto

Universidade Presbiteriana Mackenzie / Programa de Pós-Graduação em Administração de EMpresas (UPM/PPGA), SÃo PaUlo- SP, Brasil

SiLVIA MARCIA RUSSI DE DOMENICO

Universidade Presbiteriana Mackenzie / Programa de Pós-Graduação em AdMINISTRaÇão de EMPreSAS (UPM/PPGA), SÃo PAULO- SP, BRASIL

\begin{abstract}
Resumo
Em uma ontologia de fluxo, a realidade é mudança, ao passo que as organizações formais são tentativas de organização desse fluxo, a partir do trabalho de estabilização de controvérsias sob a ótica da Actor-Network Theory (ANT). Considerando essa abordagem, na qual o social é um coletivo de humanos e não humanos em redes, este estudo visa a compreender como ocorre a agência de não humanos e humanos, bem como a agência de sua associação, em processos de mudança de foco não tecnológico. Para tanto, adotou-se o estudo de caso qualitativo longitudinal, conduzido de abril de 2011 a julho de 2012 , na Empresa X, uma prestadora de serviços públicos do Estado de São Paulo, onde ocorria a implementação de um Centro de Serviços Compartilhados (CSC). Para a construção dos dados, empregaram-se observação participante, grupos de foco, entrevistas, documentos e audiovisuais, visando à multivocalidade. Mediante a cartografia de controvérsias, com o apoio de programas de redes dinâmicas, quadros e mapas mentais, descreve-se a implementação do CSC, em três escalas, de diferentes amplitudes, considerando-se dezessete anos da Empresa X. As controvérsias foram mapeadas segundo temas, argumentos, actantes e suas posições assumidas, sublinhando-se a agência de não humanos que atuaram na qualidade de mediadores. Das 40 controvérsias mais significativas, apenas 13 transformaram-se em caixas-pretas, levando o CSC a não ser pontualizado no fim da pesquisa. As principais contribuições do estudo dizem respeito à problematização do controle em processos de mudança, geralmente tomados pelas empresas como mudanças episódicas planejadas, bem como à metodologia para abordar a tentativa de organização do processo contínuo de mudança que constitui as organizações.
\end{abstract}

Palavras-chave: Mudança contínua. Abordagem orientada a processos. Fluxo. Teoria Ator-Rede. Centro de Serviços Compartilhados.

\section{Change and Actor-Network Theory: Humans and Non-Humans in Controversies for Implementing a Shared Services Center}

\begin{abstract}
In flow ontology, reality is change, while formal organizations are attempts to organize this flow, by working to stabilize controversies from the viewpoint of the Actor-Network Theory (ANT). Considering this approach, where social is a collectivity of humans and non-humans into networks, this study aims to grasp how agency by non-humans and humans takes place, as well as agency through their association, in change procedures having a non-technological focus. To do this, a longitudinal qualitative case study design was adopted, conducted from April 2011 to July 2012, at Company X, a provider of public services in the State of São Paulo, Brazil, where the implementation of a Shared Services Center (SSC) was in progress. For data construction, participatory observation, focus group, interviews, documents, and audiovisual materials were used, aiming at multivocality. Given the controversies' cartography, supported by dynamic network softwares, charts, and mental maps, the SSC implementation is described, on three scales, with various ranges, covering seventeen years of Company X. Controversies were mapped by themes, arguments, actants, and the positions they have taken, highlighting the agency of non-humans serving as mediators. Out of the forty most significant controversies, only 13 turned into black boxes, leading the SSC to be non-punctualized in the end of the research. The main contributions of the study are related to discussing control in change procedures, usually regarded by companies as planned episodic changes, as well as to the methodology for approaching the attempt to organize the ongoing change process that constitutes organizations.
\end{abstract}

Keywords: Ongoing change. Process-oriented approach. Flow. Actor-Network Theory. Shared services center.

\section{Cambio y Teoría del Actor-Red: Humanos y no Humanos en Controversias durante la Implementación de un Centro de Servicios Compartidos}

\section{Resumen}

En una ontología de flujo, la realidad es cambio, mientras que las organizaciones formales son tentativas de organización de dicho flujo, a partir del trabajo de estabilización de controversias bajo la óptica de la Teoría del Actor-Red (ANT). Considerando este abordaje, donde lo social es un colectivo de humanos y no humanos en redes, nuestro estudio tiene como objetivo comprender cómo ocurre la agencia de no humanos y humanos, así como la agencia de su asociación en procesos de cambio de foco no tecnológico. Para ello, adoptamos el estudio de caso cualitativo longitudinal, llevado adelante desde abril de 2011 a julio de 2012 en la Empresa X, una prestadora de servicios públicos del Estado de São Paulo, en la que estaba siendo implementado un Centro de Servicios Compartidos (CSC). Para la construcción de los datos, utilizamos la observación participante, grupos de foco, entrevistas, documentos y audiovisuales, buscando la multivocalidad. Mediante la cartografía de controversias, con el apoyo de programas de redes dinámicas, cuadros y mapas mentales, describimos la implementación del CSC en tres escalas de diferentes amplitudes, teniendo en cuenta diecisiete años de la Empresa X. Las controversias fueron mapeadas según temas, argumentos, actuantes y sus posiciones asumidas, subrayando la agencia de no humanos que actuaron en calidad de mediadores. De las cuarenta controversias más significativas apenas trece se convirtieron en cajas negras, llevando el CSC a no ser puntualizado hacia el fin de la investigación. Las principales contribuciones del estudio son: la problematización del control en procesos de cambio, generalmente tomados por las empresas como cambios episódicos planeados, así como la metodología para abordar la tentativa de organización del proceso continuo de cambio, que es parte constituyente de las organizaciones.

Palabras clave: Cambio continuo. Abordaje orientado hacia los procesos. Flujo. Teoría Actor-Red. Centro de Servicios Compartidos. 


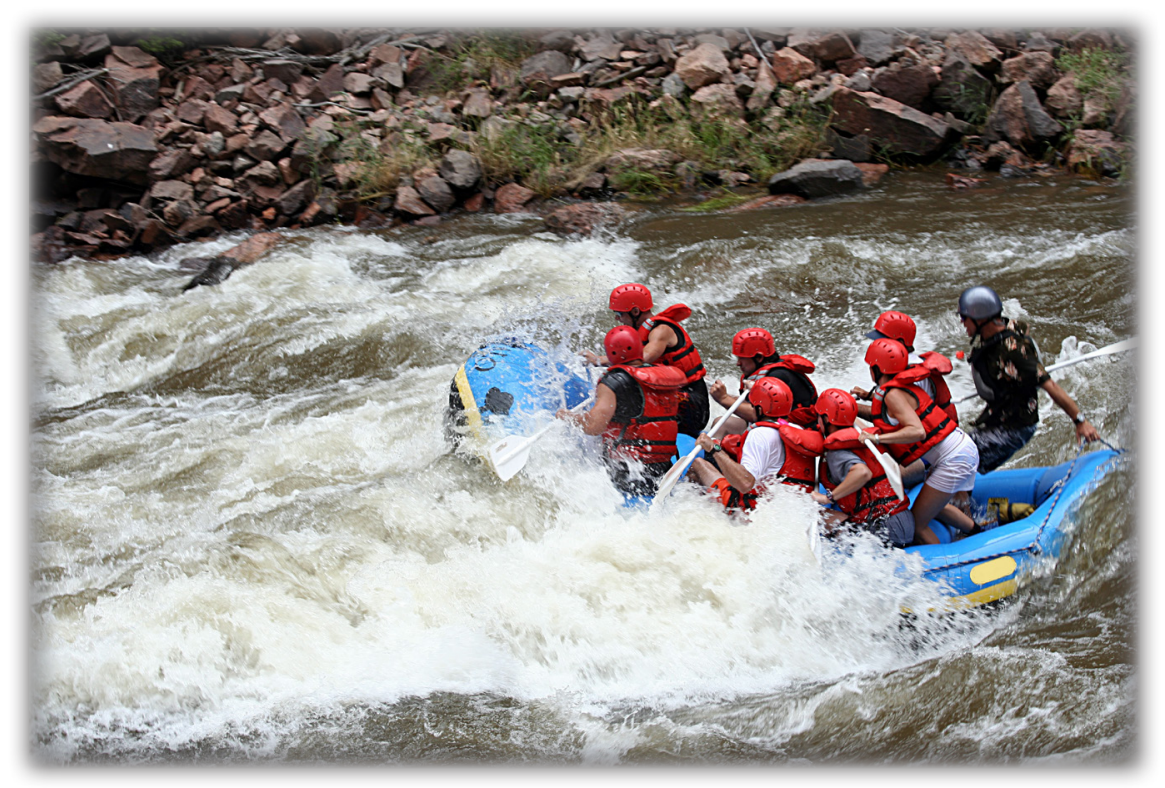

\section{INTRODUÇÃO}

Diariamente, notícias na mídia alardeiam as maravilhas ou as vicissitudes da contemporaneidade, advindas, principalmente, das mudanças tecnológicas (SCHWAB, 2011), dando-nos a impressão de que vivemos uma era sem precedentes em termos de transformações. Apesar do olhar crítico de Grey (2004), ao lembrar-nos que a mudança acabou se tornando um fetiche para os gestores no século XX, não se pode negar a velocidade dos avanços tecnológicos e a complexidade crescente das transações econômicas e sociais (CHIA, 1999).

Pettigrew, Woodman e Cameron (2001) consideram que a literatura acadêmica sobre mudança no âmbito das organizações recebeu maior impulso a partir dos anos 1960, com o advento do chamado desenvolvimento organizacional (ARMENAKIS e BEDEIAN, 1999), que acabou por disseminar uma abordagem de mudança como um fenômeno gerenciável, com contorno e duração definidos. Pettigrew $(1985,1990)$, por sua vez, foi responsável por sublinhar a necessidade de considerar questões não só de conteúdo e contexto (fatores externos e internos que deflagram as mudanças), mas também a importância de olhar para o processo ao longo do tempo, por meio de estudos longitudinais, de forma a entender o seu desenrolar, mediante os mecanismos geradores dos eventos (PETTIGREW, 2012).

Diante da necessidade de entender como e por que as mudanças ocorrem, como ressaltam autores de várias revisões clássicas da literatura de mudança (VAN DE VEN e POOLE, 1995; ARMENAKIS e BEDEIAN, 1999; WEICK e QUINN, 1999), pesquisas foram desenvolvidas com base em duas ontologias diferenciadas: de substância e de fluxo. A primeira defende que os processos levam uma entidade (um produto, ou estratégia, uma rotina, uma empresa etc.) de um estado, qualidade ou forma para outro, sem alterar sua essência. A mudança é um processo que "acontece" nas organizações. São exemplos dessa abordagem teorias de mudança que têm os "motores" (VAN DE VEN e POOLE, 1995; POOLE e VAN DE VEN, 2004) de ciclo de vida, teleológico e evolucionário como base.

Já na ontologia de fluxo, a mudança é anterior às próprias organizações. Estas são resultado da tentativa de organizar a ação humana, por meio da construção de categorias institucionalizadas que, por sua vez, têm uma estabilidade precária à medida que eventos não previstos continuam a ocorrer (TSOUKAS e CHIA, 2002), podendo levar a alterações nessas categorias e à construção de outras. 
Na perspectiva de substância, as organizações são vistas como atores sociais (MACKAY e CHIA, 2013), ao passo que na perspectiva de fluxo, são constituídas por processos organizativos em contínua transformação (CZARNIAWSKA, 2008; CZARNIAWSKA e HERNES, 2005; ALCADIPANI e TURETA, 2009) ou organizing (WEICK e QUINN, 1999).

Apesar dos esforços empreendidos considerando cada uma das ontologias, a perspectiva de processos de uma ontologia de fluxo está sub-representada em periódicos de primeira linha, segundo Langley, Smallman, Tsoukas et al. (2013). Por sua vez, no lado da prática organizacional, a ontologia da substância vem sendo a mais divulgada por consultores e pela academia nas discussões sobre estratégia entre gestores, os quais entendem as empresas predominantemente como organismos vivos, separados de seu contexto, ao qual têm de se adaptar para continuar competitivas, requerendo ações de planejamento e controle de mudanças, tomadas como fenômenos episódicos.

No entanto, as teorias de mudança na perspectiva episódica (WEICK e QUINN, 1999), que a descrevem como um processo radical (ROMANELLI e TUSHMAN, 1994), revolucionário ou evolucionário (GREENWOOD e HININGS, 1996), definido por agentes de mudança (gestores), grande parte das vezes não apresenta os resultados por eles postulados (ORLIKOWSKI, 1996; BURNES, 2005; MACKAY e CHIA, 2013). Por todas essas considerações, entendemos que caminhos via ontologia de fluxo merecem ser (re)visitados.

Nesse sentido, este artigo visa discutir mudança em organizações formais com base na Teoria Ator-Rede (Actor-Network Theory-ANT) ${ }^{1}$ que, embora tenha se desenvolvido nos estudos da ciência e tecnologia pode, a nosso ver, ser empregada para pesquisar mudança, mesmo quando o objeto de estudo não se relaciona diretamente a questões tecnológicas. Do ponto de vista epistemológico, a Teoria Ator-Rede se caracteriza como uma abordagem pós-estruturalista (LAW, 2004) e é compatível com a perspectiva de processos em uma ontologia de fluxo (HERNES, 2012; TSOUKAS e CHIA, 2002; CHIA, 1999).

Para Latour (1994), é preciso redefinir o entendimento do social e da sociedade em um mundo cada vez mais permeado pela presença de objetos que interagem com os seres humanos. Os defensores da ANT desconsideram o conceito de sociedade, abordando o social como coletivos de humanos e não humanos (objetos e quase objetos), que se associam formando redes ou, mais precisamente, formando atores-rede (LATOUR, 2005). Com base em conceitos como "híbridos" (LATOUR, 1994; 2005) e "ciborgues" (HARAWAY, 1991; HARAWAY, KUNZRU e TADEU, 2009), Bruno Latour e os demais fundadores da ANT - Michel Callon e John Law (ALCADIPANI e HASSARD, 2009) - questionam a separação entre sociedade e natureza, entre ser humano e máquina. Por meio do princípio da "simetria generalizada" dão tratamento analítico indistinto a ambos, conferindo aos não humanos a capacidade de agir e interferir no curso dos acontecimentos (CALLON, 1986; LATOUR, 1994). Sem eles, não seria possível a formação de caixas-pretas - aquilo que percebemos como estável -, até ser reabertas - o que pode ocorrer a qualquer momento.

Este estudo tem por objetivo geral compreender como ocorre a agência de não humanos e humanos e a agência de sua associação na implantação de um Centro de Serviços Compartilhados (CSC). A implementação de um CSC é, costumeiramente, visto pelos gestores das organizações que os adotam como um processo de mudança planejada. Seria o estado final desejado, em uma ontologia de substância, no qual práticas administrativas rotineiras, antes descentralizadas em diversas unidades de negócio, passariam a estar centralizadas em um único local físico, o que reduziria custos e aumentaria a competitividade (BERGERON, 2003). No entanto, colocando a lente da ANT, pretendemos mostrá-lo como uma tentativa de estabilização de uma realidade constituída de mudança, mais especificamente, de controvérsias entre atores humanos e não humanos em interação.

Latour (2005) não aceita abordagens explicativas para os fenômenos sociais, pois considera a descrição mais adequada para o entendimento de como a dinâmica social se processa. Esse autor entende que os actantes (atores humanos e não humanos) têm suas próprias "teorias" sobre o assunto, devendo o pesquisador ter a humildade de ouvir o que têm a dizer sobre a dinâmica social. No conjunto disparatado de técnicas que compõem a ANT (LAW, 2004), a "cartografia de controvérsias" emergiu como uma possibilidade analítica defendida por Venturini (2010a) e usada neste estudo para descrever a implementação do CSC.

${ }^{1}$ Usaremos o acrônimo da expressão "Teoria Ator-Rede" em inglês (actor-network theory), ou seja, "ANT" que, em inglês, significa "formiga", pois, segundo Latour (2005, p. 9, tradução nossa), esse termo era "perfeitamente ajustado para um viajante cego, míope, workaholic, farejador e coletivo [características de um pesquisador da ANT]. Uma formiga escrevendo para outras formigas ajusta-se muito bem ao meu projeto", como é o nosso. 
Ao tentar traduzir o que seria uma mudança, em princípio, episódica, olhando para as controvérsias construídas por atores-rede, as quais se estabilizam e se desestabilizam, a depender dos interesses dos actantes nela envolvidos, procuramos contribuir com a academia com uma pesquisa sobre a ontologia de fluxo, fornecendo um aporte metodológico para o estudo da mudança organizacional à luz da ANT. Com isso, procuramos vencer o desafio colocado há uma década por Van de Ven e Poole (2005), qual seja: mostrar a mudança como fluxo. Segundo esses autores, mesmo pesquisadores que partem de uma realidade descrita nessa ontologia, costumam apresentar os resultados por meio de recursos estáticos, o que vai de encontro ao fundamento ontológico do qual partiram. Neste estudo, buscamos oferecer uma tentativa de resposta a tal instigação.

Por fim, ao olhar para a mudança no âmbito das organizações por meio da Teoria Ator-Rede pretendemos dar um passo para preencher a lacuna encontrada por Wetzel e Van Gorp (2013), ao revisarem a literatura sobre mudança organizacional partindo das teorias que a embasam, apontando a baixa proporção de estudos com fundamentação teórica pósmoderna, não estruturalista, até porque tais abordagens tornam difícil tratar do gerenciamento da mudança. Em relação a esse último ponto, que toca o prisma empresarial, este estudo oferece reflexões e sugestões aos gestores para compreender a mudança em sua complexidade, colocando na berlinda a questão da gestão desse processo, a eles tão cara.

Em seguida, apresentamos o referencial teórico que amparou nossa análise, explorando os temas mudança nas organizações, Teoria Ator-Rede e a associação entre ambos, e tratamos o percurso metodológico, incluindo as questões éticas particularmente relevantes, bem como as escolhas na construção e na análise dos dados, contemplando a cartografia de controvérsias. Na apresentação e análise de resultados mostramos a descrição da implementação do CSC usando "mapas" em diferentes escalas de amplitude. Revisitamos nosso objetivo nas considerações finais, sugerindo recomendações para futuras pesquisas.

\section{MUDANÇA, ORGANIZAÇÃO E ORGANIZAÇÕES}

O interesse pelo estudo da mudança no âmbito das organizações é crescente. Ao pesquisar, em junho de 2015, artigos na base científica Scopus, na área Social Sciences and Humanites, contendo no título os termos "change" e "organization" encontramos 633 artigos, sendo que cerca de $47 \%$ deles estavam alocados na subárea de Business, Management, and Accounting, na qual se situa este artigo. Houve um expressivo aumento a partir da segunda metade da década de 1990, com uma média de 17,7 artigos entre 1996 e 2005, elevando-se nos dez anos seguintes para 38,7 publicações por ano. A centralidade da temática da mudança organizacional foi evidenciada também no Brasil, por autores como Francisco (2011), ao analisar o acervo da Revista de Administração de Empresas (RAE) de 2002 a 2010. Usando bibliometria, geoanálise e redes sociais, apontou a expressão "mudança organizacional" em segundo lugar na frequência das palavras-chave mais citadas nos artigos e de maior centralidade, superando as expressões "tecnologia de informação" e "aprendizagem".

Para Grey (2004, p. 16), o fetiche da mudança no século XX levou práticos e acadêmicos a ver esse fenômeno de forma onipresente e diferenciada em relação a outros momentos da história da civilização, levando gestores a colocar na ordem do dia a "aparente necessidade de 'gerir a mudança"” e buscar desenvolver técnicas para isso. Essa crença de tratar a mudança como algo gerenciável foi cada vez mais reforçada em razão da profusão das metáforas mecanicista e orgânica nas organizações. A primeira caracteriza o gestor como um engenheiro que substitui o que deixou de funcionar, ao passo que a segunda ao mostrar a organização diferenciada de seu ambiente, leva-o a desenhar programas de adaptação ao ambiente competitivo, antes que seja por ele descartado. Ainda, segundo esse autor, a teoria contingencial e a da escolha estratégica ganharam força ao longo do século XX, enfatizando a mudança como um fenômeno episódico, que precisa ser administrado.

Em estudo mais recente, Wetzel e Van Gorp (2013) reiteram a adoção de uma ótica racional da mudança ao longo dos últimos cinquenta anos, que contempla o uso das perspectivas contingencial, de sistemas, institucional, da visão baseada em recursos, da cultura organizacional e psicológica. Essa última, apesar de apresentar o "lado humano" das organizações para os estudos de mudança, o faz sob a ótica do desenvolvimento organizacional e das transições psicológicas que 
o indivíduo enfrenta devido aos processos de mudança, mantendo o foco em "substâncias" que passam de um estado para outro (GRAETZ e SMITH, 2010).

Weick e Quinn (1999) já apontavam como teorias de mudança compatíveis com a ideia de mudança episódica e linear o "equilíbrio pontuado", defendido por Tushman e Romanelli (1985) (intercala períodos de relativo equilíbrio com outros, breves, porém, de mudança fundamental que se tornará a base de um novo equilíbrio), organizações operando à beira do caos, apontados por McDaniel e Stacey (caos entendido como um sistema não linear simultaneamente capaz de estabilidade e instabilidade) e mudanças de segunda ordem conforme Langfield-Smith e Bougon (baseadas nos referenciais de "crenças" compartilhadas para a coordenação de ações com alterações cognitivas profundas afetando atividades e significados). A intervenção é feita mediante o processo proposto por Kurt Lewin, no fim dos anos 1940, de descongelamento, intervenção e recongelamento do novo estado proposto. Todavia, segundo Chia (1999), apesar da hegemonia da perspectiva episódica no fim do século XX, as mudanças nas organizações não vinham sendo adequadamente capturadas pelas teorias que as adotavam, por não ser suficientemente orientadas para processos. Essa constatação ao longo do tempo abriu espaço para fornecer outras lentes à pesquisa do fenômeno - lentes estas que não são novas e foram desenvolvidas paralelamente às teorias sob a ótica episódica, apesar de pouco empregadas nas organizações. Nesse sentido, Weick e Quinn (1999) apresentaram diversas pesquisas sob o guarda-chuva da perspectiva contínua da mudança, que os autores consideram mais apropriada para os estudos organizacionais diante dos contextos do século XXI.

Na perspectiva contínua, a organização é emergente e auto-organizada; a mudança, portanto, não tem começo, meio ou fim. A forma de intervenção ocorre mediante o congelamento do processo contínuo (por meio de visualização deste por mapas, esquemas e relatos), rebalanceamento (reinterpretando, alterando o sequenciamento) e descongelamento (por improvisação, translação ou aprendizado). Todos são agentes de mudança e têm relevância, não dependendo apenas daquele que iniciou o movimento, como ocorre na perspectiva episódica (WEICK e QUINN, 1999). Além do mais, o curso de mudança é incerto dependendo de contextos mutantes, assim como das ambiguidades e complexidades da ação humana (PETTIGREW, 1985, 1990; PETTIGREW, WOODMAN e CAMERON, 2001).

A mudança contínua está presente na improvisação dos diversos atores para lidar com o que emerge no cotidiano organizacional, sem muito tempo entre planejamento e execução. Por sua vez, envolve o fortalecimento de habilidades já existentes na organização. Weick e Quinn (1999) discutem ainda nessa perspectiva a mudança organizacional como um processo de translação, com base nas ideias de Latour (1986), ao afirmar que "[a] expansão no tempo e no espaço de qualquer coisa, alegações, ordens, artefatos, produtos - está nas mãos das pessoas; cada uma dessas pessoas pode agir de várias maneiras diferentes, deixando-os cair, modificando-os, desviando-os, ou traindo-os, ou adicionando-os, ou apropriando-se" (WEICK e QUINN, 1999, p. 376, tradução nossa).

Portanto, a translação depende da forma como cada pessoa entende os problemas e as formas de solucioná-los. Czarniawska (2008) aponta, corroborando essa linha de pensamento, que cada ator pode agir de maneira totalmente distinta, sendo impossível saber quando o processo será concluído pela concomitância de várias ideias diferentes ao mesmo tempo, o que acaba envolvendo-os em controvérsias - conceito a ser adotado neste estudo e definido adiante.

Em nosso entendimento, a Teoria Ator-Rede compartilha a noção de que as organizações são um fluir ininterrupto de processos se organizando, que já se faziam presentes nos estudos de organizing (WEICK, 1979). Como veremos a seguir, apesar do pensamento de processos existir há tempo na filosofia, é relativamente raro encontrá-lo no coração dos estudos conduzidos em organizações, conforme alertam Hernes e Maitlis (2012). E, quando isso ocorre, muitas vezes não se dá em uma ontologia de fluxo, prevalecendo um mundo de substâncias (CHIA, 1999) e, portanto, em uma perspectiva episódica da mudança.

\section{MUDANÇA NAS ORGANIZAÇÕES SEGUNDO AS ONTOLOGIAS DE SUBSTÂNCIA E DE FLUXO}

Fundamental para entender a defesa de uma ontologia de fluxo para estudos de mudança em organizações e, mais especificamente, por meio da ANT, é a reflexão sobre o entendimento ontológico do que sejam as organizações nas quais se investigam mudanças. Para essa discussão, é preciso nos voltarmos à filosofia e ao pensamento de Demócrito e Heráclito 
(VAN DE VEN e POOLE, 2005). Para o primeiro, a natureza seria composta por substâncias, vistas como materiais estáveis, cuja mudança só ocorreria em termos de espaço e tempo. Posição diferente tinha Heráclito, que considerava falaciosa a concepção de substância. Para ele, a realidade seria composta por processos e as substâncias seriam "produzidas por atividades variadas e flutuantes" (VAN DE VEN e POOLE, 2005, p. 1378). Hernes (2012, p. 166, tradução nossa), comentando a concepção de Heráclito, afirma que "mesmo quando coisas podem permanecer praticamente imutáveis por um período de tempo, seu significado muda com o tempo".

A despeito da posição hegemônica de seguidores de Demócrito nos séculos XIX e XX, filósofos pragmáticos e processuais, como Charles S. Peirce, William James, Henri Bergson, Whitehead e John Dewey buscaram inspiração em Heráclito, vendo "a realidade como processo e consideram o tempo, a mudança e a criatividade representando os fatos mais fundamentais para compreender o mundo" (VAN DE VEN e POOLE, 2005, p. 1378, tradução nossa). Hernes (2012) complementa, citando outros pensadores orientados para processos, como os fenomenologistas Heidegger e Schutz, e pós-modernos, como Foucault e Deleuze.

A literatura corrente sobre estudos organizacionais é profundamente influenciada por essas duas vertentes filosóficas. Para compor tal argumentação, Van de Ven e Poole (2005) analisam os trabalhos de Whetten (na linha defendida por Demócrito) e de Tsoukas (defensor da linha de Heráclito) e sintetizam a discussão ontológica sobre as organizações ao afirmar que há "duas versões do mundo social: uma, o mundo feito de coisas no qual processos representam mudança nas coisas; a outra, um mundo de processos no qual as coisas são a reificação de processos" (VAN DE VEN e POOLE, 2005, p. 1379 , tradução nossa), defendendo, por fim, que as organizações deveriam deixar de ser vistas como coisas ou entidades sociais e ser entendidas como processos organizativos em fluxo permanente. Alcadipani e Tureta (2009) compartilham esse modo de compreender as organizações ao considerá-las resultado de processos heterogêneos e multifacetados.

Ao considerar mudança, ou melhor, fluxo, anterior às organizações, resta entendê-las como resultantes de um esforço de organizar (organizing), que leva ao que Tsoukas e Chia (2002) denominam "organização". A relação de "organização" com "mudança" é algo recursivo: uma gera a outra, e vice-versa, como expressam esses autores no trecho a seguir:

[...] organização é a tentativa de ordenar o fluxo intrínseco da ação humana, de canalizá-lo para certos fins pela generalização e institucionalização de representações cognitivas particulares. [...] é um padrão que é constituído, moldado e emergente da mudança. A organização visa deter as mudanças, mas, no processo de fazê-lo, é gerada por ela (TSOUKAS e CHIA, 2002, p. 567, tradução nossa).

Os processos de organizar, quando considerados em organizações formais², resultam conjuntos de categorias institucionalizadas por meio de interação social, as quais são provisórias em razão do processo de construção social que as estabelecem (TSOUKAS e CHIA, 2002), podendo sofrer erosão, transformação ou ser interpretadas de inúmeras e imprevisíveis maneiras. Consequentemente, não há empresa como ser/substância, mas sim como constante vir a ser ou tornar-se (organizational becoming) como já apontava Chia (1999). Dessa forma, a regra é mudança e a exceção é a estabilidade, esta sempre provisória.

Langley e Tsoukas (2012, p. 2, tradução nossa) entendem que a adoção de uma abordagem de processos (entendida aqui em uma ontologia de fluxo) convida à compreensão da complexidade do mundo ao invés de reduzi-la como faria a visão hegemônica, priorizando "atividade a produto, mudança a persistência, inovação a continuidade e expressão a determinação. Tornar-se (becoming), mudança, fluxo, assim como criatividade, ruptura e indeterminismo são os temas principais de uma visão de mundo de processo".

Chia (1999) já observava que muitos estudos considerados de uma orientação de processos não chegavam de fato a usar uma ontologia de fluxo, mesmo que esse fosse o objetivo. Langley, Smallman, Tsoukas et al. (2013) reiteram esse desafio ao apresentar uma edição especial da Academy of Management Journal dedicada a trabalhos sobre mudança organizacional com base na abordagem de processos. A principal dificuldade, como fazem coro Van de Ven e Poole (2005), é conseguir mostrar as organizações, a mudança como fluxo, em movimento contínuo, como comentado na introdução

${ }^{2}$ Czarniawska (2012) defende que, ao invés de empregar o termo "organizações", deveríamos voltar a chamá-las de "empresas" nos estudos organizacionais, para evitar a confusão entre o processo de organizar e os locais onde podem ocorrer. Esse processo pode se dar em organizações formais ou fora delas, como mostram diversos estudos, como: Law (1986; 1992; 1994; 1997), Law e Singleton (2005), Tureta e Alcadipani (2011). 
deste artigo. É comum a representação de processos em palavras e diagramas que acabam fixando o que é contínuo em algo estático (uma página de artigo, por exemplo). Ultrapassar essas limitações implica aprender a pensar de forma significativamente diferente do que nossa educação fundamentada em uma ontologia de substância tem nos preparado (TSOUKAS e CHIA, 2002).

Entendemos que o emprego da Teoria Ator-Rede pode ajudar nesse sentido. Todavia, ainda são poucos os estudos em publicação definitiva que empregam a ANT para tratar de mudança nas organizações. Nesse sentido, entre 2010 e 2015, apenas seis artigos foram relacionados pela base Scopus na subárea Business, Management, and Accounting, em pesquisa feita em outubro de 2015, contendo change no título e actor-network theory como título, ou resumo, ou palavra-chave. Duas publicações (BENGTSSON e GERFALK, 2011; POLLACK, COSTELLO e SANKARAN, 2013) referem-se a mudanças tecnológicas (implantação de sistemas de informação e afins) e guardam uma aproximação ao próprio campo que serviu de berço à ANT. Apenas um artigo, de Langstrand e Elg (2012), tratou da agência específica de não humanos, na construção da resistência à mudança. Nenhum dos autores ${ }^{3}$ usou a análise de controvérsias proposta mais recentemente por Latour para lidar com problemas que atingem as sociedades, aqui focalizada em uma transposição para o âmbito organizacional.

Tais considerações nos remetem a olhar mais de perto os conceitos da ANT, bem como o de controvérsias, discutindo, por fim, se há respaldo para considerar a Teoria Ator-Rede como uma alternativa para a compreensão da mudança como fluxo.

\section{TEORIA ATOR-REDE: CONCEITOS FUNDAMENTAIS}

Com raízes nos Estudos da Ciência e Tecnologia (ALCADIPANI e HASSARD, 2009), a Teoria Ator-Rede foi desenvolvida por um grupo de sociólogos associados ao Centro de Sociologia de Inovação, em Paris, cujos pesquisadores principais são Bruno Latour, Michel Callon e John Law (NIKOLOVA, 2010), todos contemporâneos. A forma como os adeptos da ANT entendem a sociedade e o social é significativamente distinta das abordagens tradicionais da Sociologia, configurando uma nova Sociologia. Para diferenciá-las, Latour (2005) as denomina "Sociologia do Social" e "Sociologia das Associações", respectivamente.

O ritmo mais intenso das mudanças e a participação de várias entidades, principalmente a partir do século XX com a expansão da tecnologia, fariam que explicações da Sociologia do Social não fossem mais adequadas para expressar as dinâmicas da sociedade. A ANT mostra-se como uma abordagem diferenciada diante das teorias de mudanças tecnológicas que consideram, isoladamente, a atuação humana, olhando os não humanos (a tecnologia) meramente como artefatos (ALCADIPANI e HASSARD, 2009).

A consideração da agência tanto de humanos quanto de não humanos conduziu Latour a um dos aspectos mais provocativos de sua abordagem, a simetria entre os primeiros e os segundos (CZARNIAWSKA e HERNES, 2005). Nesse princípio, nenhuma das entidades é mais importante que a outra, o que levou Latour a denominá-las simplesmente "actantes", termo proveniente da linguística. Nem as distinções tradicionais entre humanos e não humanos relativos à capacidade de fala e vontade seriam suficientes para eliminar a simetria (LATOUR, 2000).

A Sociologia do Social, ao considerar que toda ação é intencional e restrita ao ser humano, limitou os objetos a uma atuação de bastidor nas ações humanas. Já na Teoria Ator-Rede, os objetos podem "autorizar, permitir, produzir, encorajar, consentir, sugerir, influenciar, bloquear, retribuir e proibir" (LATOUR, 2005, p. 72, tradução nossa). Os objetos são atores quando fazem diferença ao modificar o estado das coisas.

A relevância de cada actante humano ou não humano é definida à medida que os acontecimentos vão se sucedendo. Quando assume um papel transformador, o actante é entendido como um "mediador"; se atuar como mero transportador sem modificar a situação, é visto como um "intermediário" (LATOUR, 2005).

\footnotetext{
${ }^{3}$ Os três artigos são de autoria de Lancione e Clegg (2013), Macaulay, Yue e Thurlow (2010) e Cotton (2014).
} 
Law (1992, p. 4, tradução nossa) esclarece que a ANT não desconsidera as características dos seres humanos (corpo e vida interior), ponderando que aspectos atribuídos exclusivamente àqueles como agentes sociais seriam características de redes de humanos e não humanos denominados atores-rede:

A Teoria Ator-Rede [...] não nega que seres humanos usualmente têm a ver com seus corpos [...]. Nem nega que [...] têm uma vida interior. Entretanto, ela insiste em que agentes sociais nunca estão localizados em corpos e corpos sozinhos, mas sim que um ator é uma rede padronizada de relações heterogêneas ou um efeito produzido por tal rede. $O$ argumento é que pensar, agir, escrever, amar, ganhar dinheiro - todos os atributos que normalmente imputamos aos seres humanos são gerados em redes que perpassam e ramificam ambos, dentro e além do corpo. Por essa razão, no termo ator-rede, um ator é também, sempre, uma rede.

Uma rede seria composta por actantes sem uma hierarquia definida. A ausência de uma única entidade pode fazer toda a rede colapsar. Além disso, tais redes são "tênues, frágeis e esparsas" (LATOUR, 1993, p. 222). Law (1992) esclarece a aparente dificuldade de distinção entre actantes e redes, pois a palavra ator na expressão ator-rede é sempre uma rede.

Por exemplo, um pesquisador "Alfa" é consequência da rede de atores da qual faz parte, que reúne desde os professores e o diploma de doutorado, o computador, o celular, os participantes das pesquisas que fez, os colegas de pesquisa, os artigos em avaliação, os artigos efetivamente publicados, as revistas para as quais dá parecer, o $\mathrm{H}$-index divulgado na internet etc., ou seja, é consequência de todas essas associações. É interessante notar que o diploma de doutorado, um quase objeto, é fundamental para esse ator-rede pesquisador ser ou não reconhecido, bem como o $\mathrm{H}$-index que tem ou seu smartphone, que permite a ele (ou ela) estar conectado a diversas bases de dados em qualquer lugar do mundo. Essa identidade vai se modificando à medida que atores saem dessa rede e/ou novos são incorporados, movidos por interesses próprios. Assim, deixar de estar conectado a determinados núcleos de pesquisa irá modificar ou mesmo extinguir o ator-rede pesquisador "Alfa". Por trás de "Alfa", há um alguém, um corpo, parte de múltiplas redes, que resultam em diversas identidades (amigo, esposo, gerente, implementador de um CSC etc.) mais ou menos provisórias a depender da manutenção ou não de outros actantes (e seus interesses) a elas associados.

Quando as redes estão estabilizadas, isto é, tornam-se "caixas-pretas", podem passar a ser tratadas como blocos únicos, em um processo denominado "pontualização". Isso não quer dizer que sejam inquestionáveis, apesar da dificuldade dos actantes ao tentar abri-las (LATOUR, 2000). Interesses de um ou vários actantes podem desestabilizá-las a qualquer momento.

\section{TRANSLAÇÃO E CONTROVÉRSIAS}

A translação ou tradução, assim denominada por Latour (2000), é um dos conceitos centrais da ANT. Sua origem é atribuída aos trabalhos de Michel Serres, filósofo francês, um de seus precursores e pensador influente sobre Callon, Latour e Law.

Callon (1986, p. 203, tradução nossa) vê a translação como: "o processo geral durante o qual a identidade dos atores, a possibilidade de interação e as margens de manobra são negociadas e delimitadas". Por sua vez, Latour (2001, p. 356) conceitua translação referindo-se a "todos os deslocamentos por entre outros atores cuja mediação é indispensável à ocorrência de qualquer ação [...] as cadeias de translação referem-se ao trabalho graças ao qual os atores modificam, deslocam e transladam seus vários e contraditórios interesses".

Outra forma de ver as translações é como um processo de minimização das controvérsias advindas de diferentes interesses. Para que translações ocorram, é preciso lidar com controvérsias, fruto dos diversos interesses dos actantes envolvidos. Além disso, controvérsias podem abrir caixas-pretas (HARMAN, 2009).

Para compreender o que seria uma controvérsia, Velho e Velho (2002, p. 127) a conceituam como: "uma disputa, uma discussão ou um debate regular entre indivíduos ou grupos de indivíduos sobre um assunto de interesse comum". Esses autores discutem as possíveis revelações que o estudo das controvérsias pode propiciar sobre os interesses dos envolvidos, 
a possibilidade de entendimento dos conflitos sociais, de aspectos intangíveis da disputa, além do uso que os opositores fazem das informações. Em torno de uma controvérsia surgem grupos e antigrupos em conflito com posições opostas no debate (NOBRE e PEDRO, 2010).

Venturini (2010a) defende que as controvérsias, ao envolver todo tipo de ator, são conflitos, geram debates, mostram-se resistentes à redução da complexidade e são capazes de descrever o social em sua forma mais dinâmica. A ANT permite, por meio da análise de controvérsias, olhar para o social enquanto ele se faz, em um estado magmático (ora fluido, ora solidificado), como caracteriza Venturini (2010a), em um processo denominado "cartografia de controvérsias", empregado neste artigo e apresentado no percurso metodológico.

Antes, porém, de abordar esse tópico, faz-se necessário discutir a Teoria Ator-Rede como uma possível teoria de mudança da ontologia de fluxo.

\section{MUDANÇA NAS ORGANIZAÇÕES E TEORIA ATOR-REDE}

Langley e Tsoukas (2012), assim como Hernes e Maitlis (2012), apresentam a ANT como uma das abordagens orientadas a processos para contemplar as questões organizacionais. De forma geral, essas abordagens tratam tais fenômenos "não como fatos consumados, mas como (re)criados por meio de agentes interagindo embutidos em práticas sociomateriais, cujas ações são mediadas por artefatos institucionais, linguísticos e objetuais" (LANGLEY e TSOUKAS, 2012, p. 9, tradução nossa). A ANT, especificamente, seria "uma aplicação de visão de processos nas áreas de tecnologia, economia e organização, onde um princípio básico é o caráter emergente de entidades e onde ordenação [organização] consiste do trabalho de conectar entidades durante sua construção" (HERNES, 2012, p. 163, tradução nossa).

As entidades na ANT têm uma ontologia muito mais de fluxo, do "tornar-se" (becoming), do que possuidoras aprioristicamente de competências e capacidades, o que seria próprio de uma ontologia de substância (HERNES, 2012). No entanto, esse autor indica algumas diferenças importantes entre a ANT e, por exemplo, as teorias de organizing que mencionamos anteriormente, fundamentadas no trabalho de Weick (1979). Enquanto as segundas focalizam a criação de sentido para atores humanos, a primeira parte da premissa de que humanos e não humanos encontram-se imbricados e que o social só é reconhecido como tal pela estabilização feita pela associação de humanos com não humanos: "a ANT estuda como entidades humanas e materiais adquirem suas identidades por meio do trabalho mútuo de conexão" (HERNES, 2012, p. 164, tradução nossa), corroborado por Czarniawska (2012, p. 156, tradução nossa), ao afirmar que "esse processo [de organizing] não pode acontecer se máquinas, objetos e quase objetos, métodos cibernéticos e assim por diante, não forem acrescidos". Nessa ótica as organizações são concebidas como

[...] um conjunto de resistências superadas, um efeito precário. Seus componentes - as hierarquias, arranjos organizacionais, relações de poder e fluxos de informação - são as consequências incertas do ordenamento de materiais heterogêneos (LAW, 1992, p. 8, tradução nossa).

[...] [tais como] pessoas, máquinas, textos, prédios (LAW, 1992, p. 4, tradução nossa).

Na Teoria Ator-Rede, vale sublinhar, a noção de tempo - tão cara a qualquer abordagem de processos (LANGLEY e TSOUKAS, 2012) -, deixa de ser linear e é mais bem entendida pela imagem de uma espiral: o passado contido e protegido e o futuro representado por um círculo em permanente expansão. Nessa imagem, algo mais antigo pode estar muito mais próximo do presente do que algo que ocorreu há menos tempo (LATOUR, 1994).

Continuando sua tentativa de aproximar a ANT das abordagens orientadas a processos nos estudos organizacionais, de uma ótica de fluxo, Hernes (2012) apresenta a obra de Callon (1986), apesar do referido estudo não versar sobre uma organização formal, citando algumas características comuns a estas e à Teoria Ator-Rede. $\mathrm{O}$ artigo trata de uma controvérsia econômica e científica sobre a tentativa de domesticação de vieiras na baía de São Brieuc, na França. São descritas as negociações entre 
humanos (biólogos, colegas em congressos e pescadores) e não humanos (larvas, vieiras e bolsas coletoras) das estratégias de conservação dos moluscos daquela região francesa, com base em experiência japonesa (CALLON, 1986).

Nesse estudo três pesquisadores procuram aplicar nas larvas da espécie Pecten maximus da baía de São Brieuc uma técnica de cultivo de crustáceos, originalmente usada no Japão em outra espécie, a Pecten patinopecten yessoensis. A referida técnica consistia no uso de coletores especialmente projetados para a ancoragem das larvas de forma a permitir tanto a passagem da água quanto protegê-las dos predadores naturais durante o período de seu desenvolvimento em que são mais indefesas. Para transladar essa experiência japonesa para as vieiras francesas, os três pesquisadores procuraram estabelecer um ponto obrigatório de passagem mobilizando outros pesquisadores em congressos científicos, a comunidade pesqueira local e fazendo experimentos com larvas da espécie francesa. No início, os experimentos mostraram-se promissores, pois as larvas se ancoraram em parte dos coletores.

Contudo, depois de dez anos de atuação conjunta de biólogos, pescadores e larva, a prática não confirmou os primeiros resultados, havendo questionamentos da comunidade científica sobre as conclusões iniciais, pescadores passaram a não agir conforme acordado com seus representantes oficiais e as larvas não se ancoraram nos coletores. $O$ debate se intensificou e transformou-se em três controvérsias abordando a representatividade dos porta-vozes de cada uma das comunidades mencionadas. No "frigir dos ovos" a translação pretendida pelos três biólogos falhou, ou seja, o objetivo planejado não foi atingido (CALLON, 1986).

Com base nesse estudo, Hernes (2012) sublinha a questão da relacionalidade heterogênea. As associações que formam as redes (atores-rede) não se restringem a pessoas (os pesquisadores e a comunidade científica), envolvendo artefatos (os coletores), animais (as larvas e as vieiras) e conceitos (associações) que interagem em bases iguais.

Além disso, os atores-rede não podem ser determinados aprioristicamente. Nem as entidades constituintes da rede, nem suas identidades são estáveis, estando estas últimas sujeitas a um processo de negociação. Na concepção desse estudo "atores (pessoas, tecnologias, instituições, organizações) estão continuamente em processo de formação" (HERNES, 2012, p. 169, tradução nossa).

A contingência é vista como um fenômeno espacial nas teorias contingenciais tradicionais enquanto, naquelas baseadas em processo, como a ANT, as contingências seriam consideradas no tempo. Processos são constituídos por contingências, latentes e imprevisíveis. O processo decisório seria influenciado pela consideração do tempo, pois decisões passadas seriam tomadas partindo de informações passadas, porém, tendo um possível futuro por orientação, considerando outros possíveis futuros.

A ANT teria para Hernes (2012) uma característica de fluxo, uma vez que Callon (1986) se detém no processo pelo qual atores de materialidades heterogêneas se conectam ao longo do tempo e do espaço, transformados por meio de translações dos interesses envolvidos na rede.

Latour (2005), por sua vez, vê claramente as redes como uma forma adequada de representar fluxos. Entretanto, apesar da convicção desse autor francês, a representação de um fluxo por meio de uma rede pode não ser tão facilmente visualizada, principalmente quando se tenta fazê-lo em uma superfície plana (p. ex., no papel em que foi escrito este artigo). As associações entre actantes podem ser representadas como uma rede constituída por "nós" (actantes) e arestas (associações entre actantes). Novos actantes podem fazer parte da dinâmica social fazendo que novas associações surjam enquanto outras deixam de existir.

A representação plana permite observar apenas um momento a cada vez como fotogramas em um filme. Esse é um dos pontos de dificuldade destacados por Van de Ven e Poole (2005) na abordagem de processos de uma ontologia de fluxo, como anteriormente citamos. Todavia, se pudéssemos representar tanto os actantes quanto as associações entre eles ao longo do tempo, como se fossem três dimensões, poderíamos visualizar cada actante como segmentos de curvas (na Figura 1 - Actante A incorpora a rede a partir do momento (3), Actante B incorpora a rede do momento (1) até o momento (3) e o Actante C entre (1) e (2)). Por sua vez, as associações seriam vistas como superfícies que ligam esses actantes enquanto estiverem se relacionando (associações "ba" e "bd" representadas por superfícies que ligam os actantes $B$ com A e B com D, respectivamente, na Figura 1). 
Figura 1

Uma representação de fluxo para redes dinâmicas

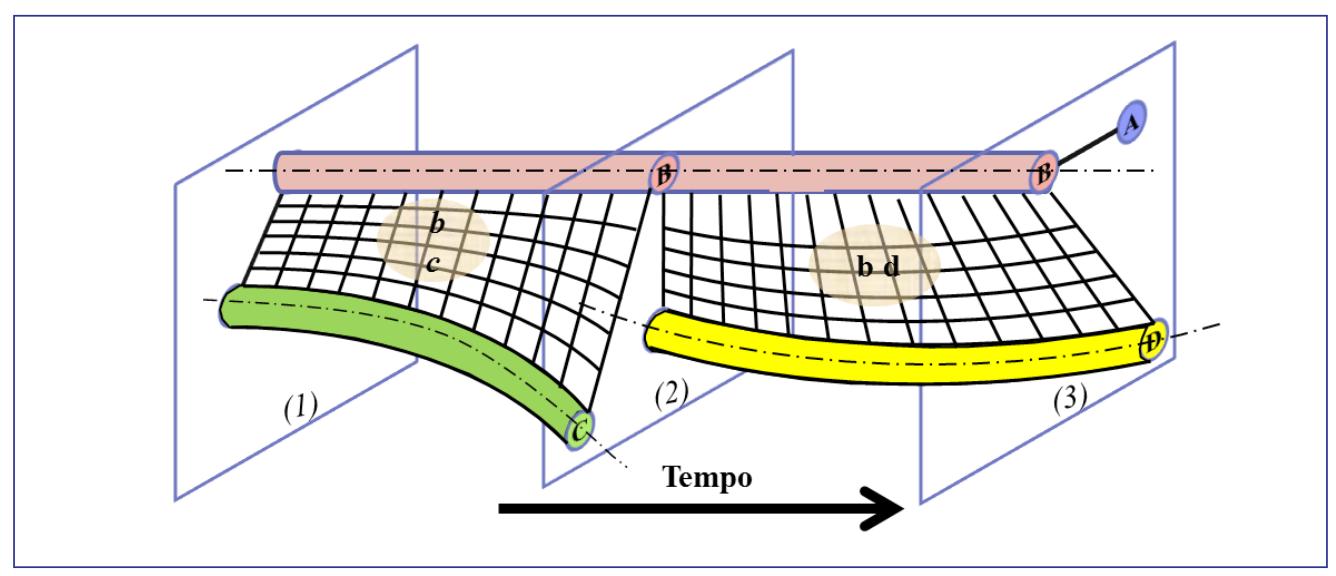

Fonte: Elaborada pelos autores.

Legenda: A - Actante A; B - Actante B; C - Actante C; D - Actante D; bc - superfície de associação entre actantes B e C; bd superfície de associação entre actantes B e D; (1) (2) e (3) são três momentos distintos e sucessivos no tempo.

Nessa representação, começamos a perceber a característica de fluxo da Teoria Ator-Rede, aproximando-a das teorias de processo. Mesmo assim, a clareza de sua representação fica comprometida quando novos actantes e associações se juntam à dinâmica social por conta do aumento de sua complexidade - desafio que tentaremos discutir com os resultados obtidos na pesquisa de campo a seguir, ao descrever o processo de implantação de um CSC.

\section{PERCURSO METOdOLÓgico}

Toda pesquisa é fruto de crenças sobre questões ontológicas e epistemológicas, que irão fundamentar as escolhas metodológicas (DENZIN e LINCOLN, 2006). Do prisma ontológico, já bastante discutido, assumimos uma realidade de fluxo/mudança, que elementos de diferentes materialidades nas organizações formais tentam, mediante esforço, organizar, construindo uma estabilidade sempre precária. Coerentemente com essa ótica, escolhemos a ANT como uma lente teórica para nos guiar nessa ontologia. Em termos epistemológicos, a Teoria Ator-Rede carrega características pós-estruturalistas (LAW, 2004). Latour (1994), no entanto, não reconhece esse rótulo, preferindo colocar-se como um não moderno. Ao se mencionar o moderno, está subjacente uma concepção linear de tempo, em que o passado é arcaico, antigo e superado e o moderno algo novo constituído por ganhadores; quanto mais tempo decorrido, mais distinto da realidade vigente. Como comentado no tópico anterior, o tempo na ANT é visto como uma espiral, em que o passado, por vezes, está mais perto do presente do que o futuro. Além disso, para esse autor, o moderno jamais teria existido em suas bases humanistas. Importante ressaltar que, na Teoria Ator-Rede, não se buscam explicações (estruturas subjacentes), mas, sim, descrever o social tão bem quanto seja possível (LATOUR, 2005). A seguir apresentamos as escolhas metodológicas para isso.

\section{Estratégia de pesquisa}

A abordagem de uma situação específica é uma das características da ANT para o entendimento de seus conceitos na prática (LAW, 2007). Neste estudo, analisamos uma situação específica na empresa escolhida, durante um período. Em outras palavras, estudamos um caso. Stake (2005, p. 443, tradução nossa) considera que o "estudo de caso não é uma escolha metodológica, mas uma escolha do que será estudado". O interesse é, no caso, aquilo que 
pode ser aprendido dele, exigindo profundo exame de como as "coisas" acontecem. Nesta pesquisa, estudamos a implementação de um CSC na Diretoria de Operação da RMSP na Empresa X, entendida gerencialmente como uma mudança planejada.

Pettigrew, Woodman e Cameron (2001) tecem críticas sobre a prevalência de estudos transversais sobre mudança em detrimento daqueles que abordam processos mais complexos no tempo e no espaço, que revelam aspectos da dinâmica da mudança. Portanto, a necessidade da proximidade do pesquisador e a inadequação de abordagens transversais para estudos de mudança convergiram para uma abordagem longitudinal.

O estudo demandou catorze meses para a construção dos dados. O marco adotado para "congelar" o processo contínuo de organizing (WEICK e QUINN, 1999; ORLIKOWSKI, 1996), foi 07/04/2011 quando foi aprovada a "implementação do CSC", tendo se estendido até 30/06/2012. Durante esse período acompanhamos in loco os acontecimentos para descrevê-los. Ocorrências anteriores foram obtidas pelo depoimento de atores ou por documentos.

\section{A organização}

A pesquisa foi conduzida na Empresa $\mathrm{X}$ - uma empresa de economia mista de prestação de serviços públicos ligada a uma das secretarias do Governo do Estado de São Paulo, que tem em seu quadro mais de 5 mil empregados. Sua estrutura organizacional é composta pela Presidência e cinco diretorias, a saber: Operação da Região Metropolitana de São Paulo (RMSP); Operação do Interior; Técnica; Administrativa; e Financeira.

A diretoria administrativa é organizada em cinco superintendências funcionais, a saber: RH; Suprimentos e Contratações; Tecnologia da Informação; Patrimônio e Serviços; e Jurídica. Essas superintendências têm o papel de "autoridade funcional”"4.

A Diretoria de Operação da RMSP é constituída por sete unidades de negócio (cinco regionais pelo critério geográfico e duas de produção, com produtos omitidos por sigilo) e três superintendências temáticas (Empreendimentos; Manutenção; e Planejamento). Ocorre semanalmente o "fórum da diretoria", reunião liderada pelo diretor com seus assessores e superintendentes. A estrutura de uma UN típica é constituída por departamentos, a saber: Serviços; Engenharia; Administrativo; e Planejamento. Um departamento administrativo típico tem áreas "informais": Gestão de RH (GRH); Desenvolvimento Humano (DH); Tecnologia da informação (TI); Patrimônio e Serviços (PS); Suprimentos e Contratações (SC); Jurídico (JUR); e Financeiro (FIN). Os gerentes e gestores administrativos organizam "fóruns" mensais.

\section{O caso: a translação objeto do estudo e seus participantes}

A translação pesquisada neste estudo foi a "Implementação do CSC" na diretoria de operação da RMSP, que constituiu a partir de 2011 um projeto da Empresa X.

Bergeron (2003, p. 3) define serviços compartilhados como:

[...] uma estratégia colaborativa na qual um subconjunto de funções de negócios existentes é concentrada numa nova unidade de negócio semiautônoma, que tem uma estrutura gerencial projetada para promover eficiência, geração de valor, redução de custos e melhoria dos serviços para clientes internos da corporação pai, como um negócio competindo no mercado aberto.

Quinn, Cooke e Kris (2000) apontam os tipos de serviços que potencialmente podem ser objeto de compartilhamento das funções financeiras, RH, TI, suprimentos e suporte. Quanto ao tipo, poderiam ser "transacionais e administrativos" e "profissionais e técnicos".

Questões críticas que aparecem como dificuldades ou resistências podem ser foco de conflitos. Nesse sentido um conjunto de pontos indicados pela literatura de CSC (SCHULMAN, DUNLEAVY, HARMER et al., 1999; BERGERON, 2003; QUINN, COOKE e KRIS, 2000) merecem atenção durante a implementação de um CSC. São eles: (a) o debate centralização e

\footnotetext{
${ }^{4}$ São atribuições de uma Autoridade Funcional: planejar; acompanhar o estado da arte; orientar; padronizar processos; monitorar e consolidar informações para a Alta Administração; e posicionar-se sobre temas complexos.
} 
descentralização; (b) a escolha do gerente; (c) a escolha da equipe; (d) a localização do CSC; (e) adoção da estratégia de big bang ; (f) o momento de realização da reengenharia de processos; (g) gestão de mudanças; (h) o aporte tecnológico; (i) resistência gerencial; (j) o suporte metodológico externo; e (k) precificação e o acordo de nível de serviços.

A implementação do CSC emergiu de um estudo prévio sobre o modelo de gestão administrativo da diretoria de operação da RMSP, feito por uma consultoria empresarial. O tempo total previsto para a implementação era de 1,5 ano.

Conhecidas as características da organização e da translação envolvida no estudo, passaremos a discutir como a pesquisa de campo foi feita à luz da ANT. Antes disso, todavia, é importante iluminar as questões éticas envolvidas no estudo.

\section{Os interesses do pesquisador e o trato das questões éticas}

O primeiro autor deste artigo, um ator-rede constituído por três identidades (pesquisador, gerente de uma das unidades envolvidas na mudança e implementador do CSC) teve de enfrentar desafios de natureza ética em razão de seus conflitos de interesse de cada uma dessas identidades. Compartilhamos algumas dessas dificuldades vivenciadas na construção e análise dos dados desta pesquisa na Figura 2.

Figura 2

Os interesses e conflitos éticos do ator-rede pesquisador-gerente-implementador

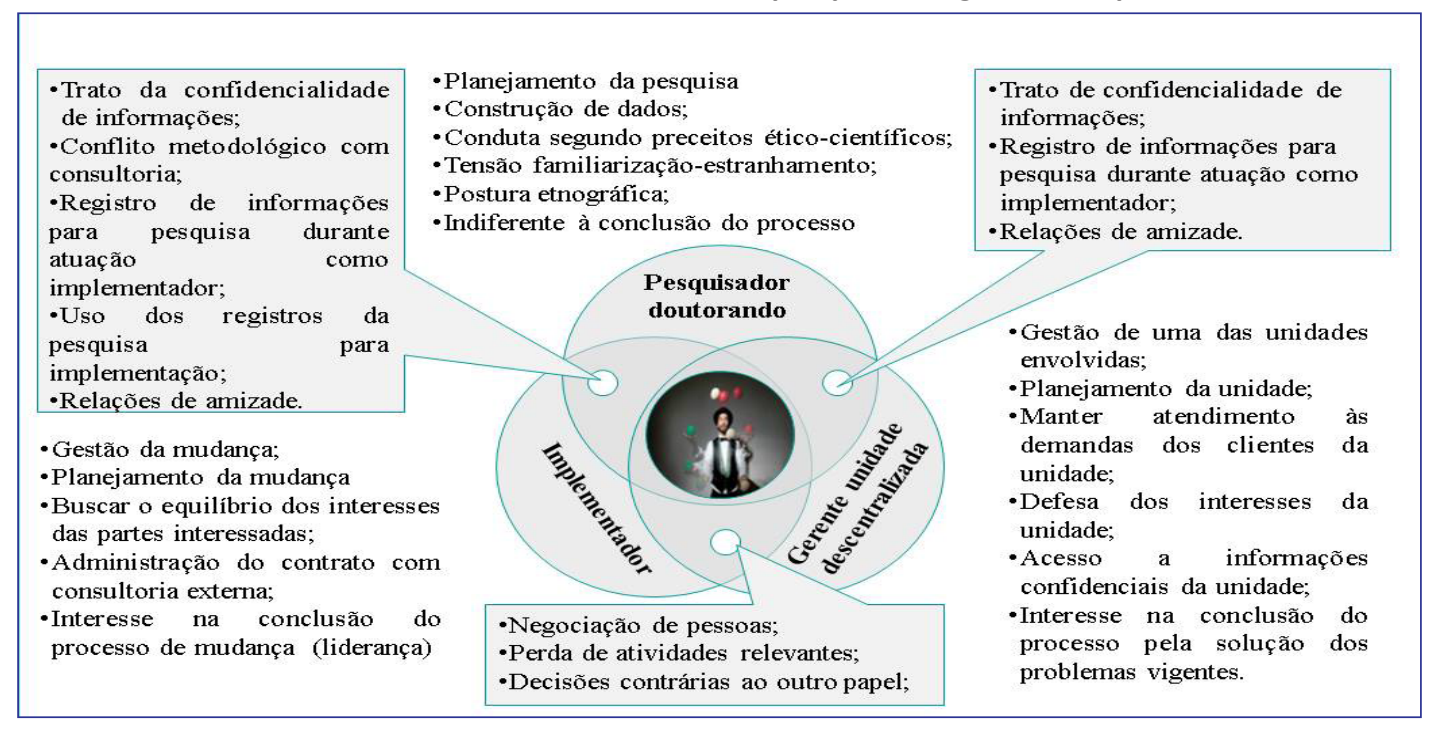

Fonte: Elaborada pelos autores.

Cuidados de natureza ética, tanto no âmbito empresarial (autorização da Empresa X) quanto no acadêmico (Comitê de Ética da Universidade ${ }^{6}$ ), foram tomados para que a pesquisa pudesse ser feita a contento. $O$ relacionamento com as pessoas é um ponto relevante, pois durante uma pesquisa o pesquisador pode implicar os membros constituintes da rede mencionada. Relações de amizade entre o pesquisador e os demais integrantes no ambiente de pesquisa são particularmente delicadas em pesquisas nas quais o pesquisador faz parte do ambiente social onde a pesquisa será conduzida demandando atenção (ELLIS, ADAMS e BOCHNER, 2011). Barbour (2009) salienta a relevância da questão ética também para grupos preexistentes em uma pesquisa. Tendo esse conjunto de preocupações em mente, buscamos tomar outras medidas para tratar as referidas questões éticas: (a) Manutenção do sigilo em situações como: Setor da economia na qual atua; Secretaria de governo a que está vinculada, alteração da denominação das UN para não

\footnotetext{
${ }^{5} \mathrm{~A}$ estratégia de big bang consiste em uma abordagem de implementação para início rápido do CSC. É empregada, usualmente, para suplantar lideranças fortes de unidades de negócios. O efeito, no entanto, é uma ruptura com empregados e com as operações do dia a dia. Decisões são tomadas rapidamente, por vezes, com barganhas com as UN e não partindo de considerações de longo prazo (SCHULMAN, DUNLEAVY, HARMER et al., 1999). ${ }^{6}$ Processo CEP/UPM n. 1457/5/2012, de 25/06/2012.
} 
permitir a identificação da Empresa X; Situações sensíveis de natureza psicológica; Questões estratégicas, não relacionadas ao estudo; Informações sigilosas manifestas ao pesquisador ou de actantes não humanos; e (b) Realização de: Esclarecimentos em reuniões; Compartilhamento pontual de informações da pesquisa, que facilitassem o processo de mudança, resguardado o sigilo; Consulta a actantes humanos de subprodutos da pesquisa "durante a análise de dados" avaliando sua aderência; Nos grupos de foco foi esclarecido que se tratava de uma pesquisa científica e não de uma reunião regular.

\section{Como foi feita a pesquisa}

Latour (2005) acredita que a compreensão das dinâmicas do dia a dia ocorre pela identificação e descrição meticulosa da situação. Por essa razão, aponta a relevância da postura do etnógrafo na construção de dados em campo, não para identificar a cultura, mas, sim, pela capacidade olhar para o campo, identificando elementos relacionados sem buscar dissociá-los. Seguir pari passu os actantes permite identificar humanos e não humanos, que poderiam passar despercebidos. Neste estudo, buscamos adotar a postura do etnógrafo.

Angrosino (2009, p. 56) conceitua a observação como "o ato de perceber as atividades e os inter-relacionamentos das pessoas no cenário de campo através dos cinco sentidos do pesquisador", salientando a importância do pesquisador despender um esforço significativo para captar os detalhes de uma dada situação.

Em nosso estudo, o primeiro autor era membro da organização e do processo sob investigação, o que acarretou alguns cuidados, adotados a partir da autoetnografia. Essa abordagem vale-se de princípios da autobiografia e da etnografia (ELLIS, ADAMS e BOCHNER, 2011), sendo o pesquisador um cruzador de fronteiras, com duas identidades: pesquisador e nativo (REED-DANAHAY, 1997). Para Ellis, Adams e Bochner (2011), é possível relatar suas próprias experiências, quando quem o faz é um pesquisador. Um ponto importante nessa condição de pesquisador-nativo é a atenção à tensão entre familiaridade e estranhamento, ou seja, a conciliação por parte do pesquisador entre proximidade e distanciamento em relação aos participantes (JAIME, 2009). Esse ponto é relevante neste estudo, pois o pesquisador tinha significativa familiaridade com a empresa e com os acontecimentos em curso, exigindo um esforço de distanciamento.

Neste estudo, realizamos observação participante em todas as reuniões como implementador, envolvendo-nos em debates das controvérsias por meio da emissão de argumentos, na tomada de decisões, no contato com diferentes níveis hierárquicos da Empresa $X$ e de outras empresas, instituições, órgãos que participaram da translação em estudo. Durante tais reuniões tomamos notas para registrar aspectos relevantes, procuramos adotar o Princípio da Simetria, buscando observar tanto a agência de actantes quanto de suas associações.

Depois da tomada de notas, durante os acontecimentos, elaboramos relatos descritivos detalhados das dinâmicas sociais presenciadas para compor o "diário do projeto" (171 relatos pormenorizados, em um total de 451 páginas). Os registros sistemáticos de campo do processo de mudanças do pesquisador, como um etnógrafo, que passaram a agir como actantes, uma vez que produziram ações no implementador da mudança (pesquisador) que talvez não tivessem ocorrido sem a leitura (e reflexão) de tais relatos.

Concomitantemente aos registros de observações, identificamos e arquivamos documentos para subsidiar o estudo, salientando os dois papéis que tiveram na pesquisa: (a) tradicional, como fontes de informação para a pesquisa qualitativa (CRESWELL, 2007); e (b) actantes (à medida que suas "ações" mudam o curso dos acontecimentos). Foram arquivados 830 e-mails, atas de reuniões, estudos internos e de consultorias, memorandos, rascunhos, notícias na mídia interna, outros documentos externos e procedimentos. Em situações pontuais outros actantes não humanos (como apresentações ou relatórios) foram obtidos retrospectivamente por sua relevância. Além das fontes textuais, consideramos vídeos de reuniões relevantes.

Para propiciar a multivocalidade, seguindo Angrosino (2009), demos voz a outros actantes, para além dos pesquisadores. Essa multiplicidade de fontes de observação é defendida por Venturini (2010a). Para tal lançamos mão de entrevistas, individuais e coletivas, visando a: (a) obter uma visão diversa do pesquisador em relação à dinâmica dos acontecimentos; e (b) identificar elementos distintos daqueles observados pelo pesquisador. Decidimos pelo uso de entrevistas focalizadas orientadas por um roteiro. Nesta pesquisa foram entrevistadas cinco pessoas: o diretor, a gerente do CSC, os 
superintendentes das UN Centro e Sul e o consultor. Foram organizados também dois grupos de foco: o primeiro com o fórum administrativo e o segundo com os gestores subordinados ao pesquisador-gerente.

O moderador do grupo focal tem papel relevante na dinâmica e nos resultados obtidos (BARBOUR, 2009). Os grupos de foco e as entrevistas individuais foram conduzidas pela mesma pessoa, a coautora, tendo em vista a possível dificuldade dos entrevistados em criticar o processo liderado pelo pesquisador. $O$ discurso dos entrevistados também poderia ser fragmentado por referências a acontecimentos vivenciados por ambos, entrevistado e pesquisador, caso o moderador fosse o primeiro autor.

Depois da construção dos dados mediante observação participante, documentos e entrevistas, houve a tarefa de tratá-los e analisá-los.

\section{Procedimentos de tratamento e análise dos dados}

Law (2007) caracteriza a ANT como um conjunto disparatado de técnicas analíticas das mais diversas origens, a ponto de dizer que não existe uma única ANT. As incertezas e as indefinições metodológicas existentes sobre como analisar os dados levantados em campo sugerem ser esta ainda uma lacuna a ser preenchida (MITEV, 2009), uma oportunidade para este estudo.

Entre as opções analíticas, Latour (2001) destaca a possibilidade da adoção dos conceitos de cartografia. Nobre e Pedro (2010) sugerem a adoção desse método para registrar e analisar os diferentes momentos da translação, especialmente as controvérsias tão presentes em processos de mudança. A cartografia vem sendo desenvolvida e adotada por Latour ao longo do tempo e, com mais ênfase, em tempos recentes, para a análise de controvérsias. Foi nossa opção para o tratamento e a análise dos dados neste estudo. Tal abordagem aparece no projeto de pesquisa europeu denominado Mapping Controversies in Science and Technology for Politics (Macospol), implementado e liderado por Latour, desde 2007, em associação com diversas instituições de ensino no mundo.

Venturini (2010b, p. 4, tradução nossa) caracteriza os debates da cartografia de controvérsias como "a melhor forma de observar a construção da vida social". Latour adota a cartografia para discutir como se constrói a ciência (VENTURINI, 2010a). Nosso interesse é nos estudos organizacionais, especificamente, para entender a dinâmica social em uma suposta mudança organizacional. Para tal necessitamos compreender como ocorre a constituição de caixas-pretas a partir da estabilização de controvérsias. Portanto, o entendimento de como controvérsias se desenvolvem ao longo do tempo é essencial para este estudo.

É importante para o cartógrafo de controvérsias usar o maior número possível de ferramentas de observação, dando visibilidade a diferentes pontos de vista, considerando sua representatividade (afirmações ou argumentos compartilhados por vários actantes deveriam ter maior visibilidade), influência (actantes com posição de influência merecem tratamento diferenciado) e interesse (considerar as minorias e não apenas posições majoritárias) (VENTURINI, 2010b). Procuramos dar voz a diferentes grupos de interesse mediante a observação participante e das demais fontes de evidência, considerando diferentes manifestações dos actantes, diferentes posições hierárquicas, o posicionamento de maiorias e minorias, convergências e divergências entre actantes na dinâmica social cartografada.

Venturini (2010b) destaca que a tarefa de agregação de informações tornou-se mais fácil de ser efetivada. Pesquisadores podem lidar com vastas quantidades de informações, algo inviável até o advento das tecnologias digitais, além de poder agregar também as vantagens da pesquisa qualitativa. Dessa forma, preocupamo-nos em selecionar recursos digitais para facilitar o tratamento dos dados. O ponto de partida para o tratamento dos dados foi o diário de campo. Fizemos sua análise por meio de uma leitura flutuante do texto, visando a identificar elementos envolvidos na dinâmica social: reuniões, actantes, controvérsias, caixas-pretas, argumentos e decisões. Aspectos sigilosos foram omitidos, atendendo a preceitos éticos.

Esse mesmo processo foi adotado nas outras fontes de evidência para fornecer outros pontos de vista, além daqueles do pesquisador. Merece destaque a seleção dos e-mails mais relevantes. Dos 830 reunidos, foram selecionadas 288 mensagens, sendo de três tipos principais: e-mails diretos entre um emissor e um receptor; troca de e-mails entre duas pessoas; e cadeia de e-mails. Para avaliar a relevância de tais e-mails foram considerados os seguintes critérios: (a) Para inclusão do e-mail: envolvia o diretor; versavam sobre assuntos não abordados em outras fontes; envolviam decisões; fontes de novas controvérsias; divulgações amplas de conteúdo; enviados pelo celular do implementador; envolviam conflitos; relatórios de andamento do projeto; encaminhavam não humanos relevantes (apresentações e relatórios); e (b) Para exclusão do e-mail: Assuntos sigilosos; e-mails intermediários da cadeia de e-mails; informações 
pontuais que não afetaram a dinâmica estudada; envolvimento de atores com participação pontual e de baixa relevância; não associados a controvérsias.

Todos os elementos identificados, exceto entrevistas e grupos de foco, foram inseridos no programa Gephi 0.8 , permitindo a inserção de dados dos actantes, controvérsias, caixas-pretas, argumentos e decisões como nós e suas associações registradas como arestas. Os nós e as arestas têm entre seus atributos o tempo de duração. A entrada dos dados foi manual, tendo reuniões como ponto de partida. Como ressalta Latour (2005) ficamos "afogados em dados"7.

Refinados os dados, passamos a analisar o desenvolvimento da dinâmica social ao longo do tempo por meio das associações entre os actantes envolvidos na translação em estudo, olhando agora para as controvérsias. Passamos a lançar mão de outros recursos disponíveis no próprio programa, como filtragem, distribuições dos dados, métricas de análise de redes dinâmicas. Para mostrar as controvérsias presentes no ambiente organizacional e as caixas-pretas foi elaborado um gráfico de Gantt, usando o programa Timelinemaker Professional.

Finalmente, merecem destaque na análise de dados, as árvores hierárquicas recomendadas por Venturini (2010b). Construímos mapas mentais por controvérsia com diferentes níveis na ramificação, cada um deles constituído por um tipo de elemento diferente, a saber: (a) 1ํ nível - "temas": dependendo da complexidade, uma controvérsia pode levar ao debate de diferentes aspectos; (b) 2 ㅇ nível - "posições": entendidas aqui como convergência dos actantes sobre uma das possibilidades de resolução da controvérsia (implícita ou explicitamente declaradas); (c) 3o nível - "argumentos": usados pelos actantes durante os debates em prol de uma posição; (d) 4o nível - "actantes humanos e não humanos": envolvidos em cada argumento; (e) ramo principal: apontando as controvérsias relacionadas.

Uma última palavra neste item precisa ser dita em relação às demais fontes de evidência. Inicialmente, fizemos as transcrições de entrevistas, grupos de foco e filmagens, as quais foram analisadas para compor, com as demais, critérios para a identificação da relevância de determinados elementos. Como comentado anteriormente, as informações oriundas de entrevistas individuais e grupos de foco não foram registradas no Gephi, pois percebemos que poderiam ser introduzidas distorções (diferentes percepções sobre "o quê", "quando" e "quem" fez algo). Portanto, decidimos separar os dados obtidos longitudinalmente por observação participante, daqueles levantados transversalmente por entrevistas individuais e grupais.

\section{A redação da descrição de Implementação do CSC}

Seguindo Venturini (2010b), mapas acompanham a exploração do estudo do cartógrafo social. Mais do que espelhar a complexidade, como afirma Venturini (2010b), tais mapas "têm que fazer tal complexidade legível". Entendemos que tal recurso é particularmente útil para descrever um processo de mudança de diferentes óticas. Nesse sentido, a descrição foi feita em três escalas sucessivamente maiores em detalhamento e menores em amplitude: (a) Escala menor (maior amplitude e menor detalhamento); (b) Escala intermediária (amplitude e detalhamento intermediários); e (c) Escala maior (menor amplitude e maior detalhamento). Neste artigo, tendo em vista os objetivos relacionados à agência de não humanos e humanos e sua associação, enfatizaremos a última escala, que aponta em detalhes duas controvérsias e as ações de não humanos em interação com humanos, deixando para as duas primeiras o entendimento geral do processo de mudança e do conjunto de controvérsias.

Destacamos, neste percurso metodológico, a inserção ao longo da descrição dos resultados, de hiperlinks dos endereços eletrônicos de vídeos hospedados no Google Drive, mostrando a construção do social em sua dinâmica como primeiro passo para responder ao desafio de Van de Ven e Poole (2005) quanto à representação da mudança de uma ontologia de fluxo.

\section{Apresentação e análise de resultados}

Antes de iniciar as descrições apontamos os principais movimentos organizacionais da Diretoria que implementou o CSC. Entendemos que não há como se falar de início efetivo de um processo de mudança, partindo da consideração da

\footnotetext{
${ }^{7}$ O volume de dados neste caso foi significativo, tendo sido inseridos no programa Gephi 0.8: Controvérsias: 190; Actantes: 2.069, sendo humanos (diretores, assessores, superintendentes, gerentes, implementador etc.) 427 e não humanos divididos em três tipos, atores institucionais (UN, superintendências, grupos, empresas, órgãos públicos etc.): 259, quase objetos (documentos, leis, relatórios, e-mails): 1.240 e objetos (celulares, carros etc.): 143; reuniões (reuniões, treinamentos etc.): 485; argumentos (dos actantes defendendo posições): 5.854; decisões: 99; associações entre esses elementos (Arestas): 39.695.
} 
mudança como contínua. Entretanto, para propiciar maior compreensão dos acontecimentos durante a descrição da translação, elegemos marcos temporais delimitadores de períodos nos quais movimentos relevantes aconteceram. Os movimentos e os respectivos períodos considerados foram: regionalização do SESMT (de 08/2008 a 11/2008); mapeamento de processos (de 11/2008 a 08/2010); novo modelo de gestão administrativa da diretoria de operação RMSP (de 08/2010 a 04/2011); implementação do CSC - planejamento" (de 04/2011 a 12/2011); e implementação do CSC - início de operação (de 01/2012 até 30/06/2012). Nos três primeiros períodos foram usadas fontes secundárias. Os últimos dois foram construídos com base em observação participante e fontes secundárias. Tais movimentos foram percebidos retrospectivamente e serão mais bem situados na descrição a seguir.

\section{Escala menor: um olhar mais abrangente}

A translação objeto deste estudo é a Implementação de um CSC na Diretoria de Operação da RMSP da Empresa X. Esta mudança não surgiu como um projeto definido no primeiro momento, mas sim como uma cadeia de acontecimentos que nele redundaram.

O primeiro movimento organizacional foi o projeto de regionalização do Serviço de Engenharia de Segurança e Medicina do Trabalho (SESMT) com a proposição de uma nova forma de organização desse serviço, tornando-o independente da estrutura dos departamentos administrativos da UN. Essa proposta foi feita por uma das médicas do trabalho ao fórum da diretoria em julho de 2008, porém, depois de análise dos gerentes administrativos, não foi aceita.

Em novembro de 2008, o diretor convocou os gerentes administrativos para discutir o desempenho deles. Os departamentos eram vistos pelos seus superintendentes como burocráticos, lentos e com atuações despadronizadas. A solução divisada pelos gerentes administrativos para tal crítica foi o desenvolvimento de um projeto de mapeamento de processos com apoio metodológico de uma consultoria. O início do projeto ocorreu em julho de 2009, em razão do processo licitatório e da contratação. Depois de quase um ano, o estudo não foi concluído devido a divergências com o consultor e à interferência de estudos corporativos de redução de custos.

Em agosto de 2010, nova reunião entre o diretor e os gerentes administrativos tratou de dois assuntos: a continuidade do projeto de mapeamento de processos com outra consultoria e a apresentação de um estudo para formalização dos gestores ${ }^{8}$. O diretor não aceitou as propostas por discordar da forma pela qual os departamentos administrativos estavam organizados. Considerou que sua anuência aos projetos implicaria a continuidade da referida forma de organização. O diretor, então, demandou novo estudo, desta vez de curto prazo, para discutir o Modelo de gestão administrativa da diretoria de operação RMSP. Para isso deveriam contratar uma nova consultoria com o objetivo de, em três meses, estudar outras formas de organização administrativa. Esse projeto teve início em dezembro de 2010, depois da conclusão de novo processo licitatório, e se estendeu até março de 2011 com levantamento de dados e proposição de criação de um CSC. A implementação do CSC deveria ocorrer em "ondas de mudança" por função administrativa (1ao onda - RH; 2aㅡonda - Tl; 3a onda - Suprimentos e contratações; 4a onda - Patrimônio e Serviços; 5 a onda - Jurídico; e 6a Onda - Financeiro). O tempo inicialmente previsto para implementar todas as ondas era 1,5 ano. A proposta foi apresentada e aprovada em uma reunião do fórum da diretoria em 04/04/2011.

Em 14/04/2011, o gerente administrativo da Manutenção (primeiro autor deste artigo) foi designado pelo diretor como implementador do CSC, dando início às tratativas para um processo licitatório a fim de contratar uma nova consultoria para o processo de implementação. $O$ implementador organizou com o fórum administrativo uma reunião em 16/06/2011 para marcar a implementação do CSC, reunindo as lideranças administrativas da diretoria.

O projeto de implementação do CSC teve início em setembro de 2011 com os debates sobre segmentação de atividades CSC versus departamentos administrativos, dimensionamento de pessoal e a escolha do gerente do CSC. Em dezembro de 2011, ocorreu a reunião de planejamento tático da diretoria de operação RMSP na qual o projeto de implementação do CSC passou a constar como macroação da diretoria. Depois da definição da gerente do CSC em 16/12/2011, intensificaram-se as discussões para formalização de sua estrutura. A apresentação do projeto CSC para o colegiado de diretores ocorreu em janeiro de 2012.

Em fevereiro de 2012 iniciaram-se as atividades do CSC, ainda a título informal, com a migração de profissionais e atividades definidas. Em 15/02/2012, uma reunião de início de atividades do CSC envolveu todos os gerentes dos departamentos operacionais, clientes finais do CSC.

\footnotetext{
${ }^{8}$ Os gestores são lideranças informais existentes na empresa em decorrência de downsizing ocorrido em 2003.
} 
Nos meses subsequentes (até junho de 2012, quando encerramos a construção dos dados), as migrações de profissionais da 1a onda (RH e DH) foram concluídas, enquanto a 2a e a 3a ondas (TI e "Patrimônio e Serviços", respectivamente) encontravam-se em discussão.

\section{Escala intermediária: mapeando as controvérsias}

A escala intermediária é marcada por um olhar mais próximo da dinâmica social no qual podemos divisar as controvérsias que eclodem ou se encerram ao longo do tempo. Quanto mais nos aproximamos, mais detalhes são vislumbrados, evidenciando a complexidade do processo de mudança em estudo. Podemos depreender tal complexidade por conta da diversidade e quantidade significativa de elementos identificados na análise das fontes de evidência. A visualização inicial do diagrama acumulado mostra a profusão de tipos de actantes e de associações ocorridas ao longo do período considerado de análise (Figura 3). Entre os elementos participantes da dinâmica social aparecem as controvérsias (pontos brancos) como aglutinadores temporários dos debates entre os diferentes actantes humanos e não humanos.

Figura 3

\section{Visualização dos elementos da dinâmica social da translação em estudo}

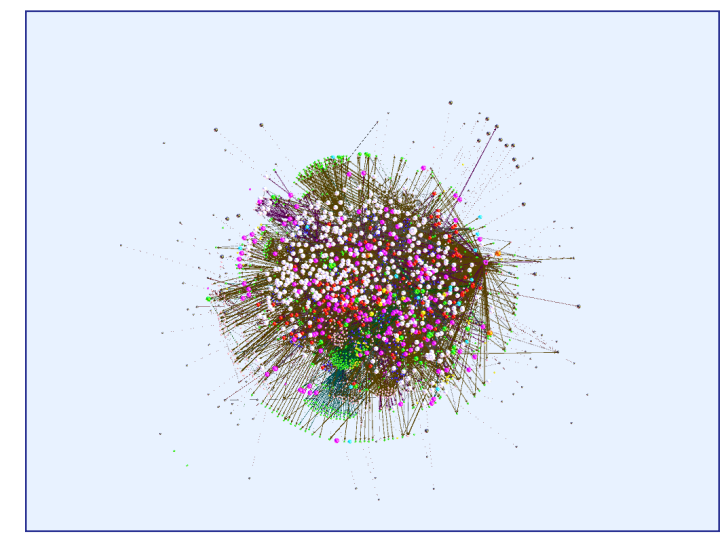

Fonte: Elaborada pelos autores.

Acessando o endereço abaixo, é possível ver o desenrolar do conjunto de movimentos organizacionais descritos e as controvérsias associadas em sua dinâmica no tempo até chegar à "foto" do acumulado de dados, contemplada na Figura 3: <https://drive.google.com/file/d/OBxfyYI2ztV_IS1M0bXZ1Zk5BOFU/view?usp=>

A primeira análise dos dados provenientes dos diários de campo gerou um cenário com 230 controvérsias "brutas". Um refinamento redundou em uma redução para 190. Uma análise do conjunto de controvérsias e argumentos usados pelos actantes revelou a concentração de parte significativa dos argumentos em um rol de controvérsias. De maneira análoga, ao observar o conjunto de controvérsias e reuniões, também notamos que algumas delas foram debatidas em diferentes reuniões. Portanto, um critério de seleção de controvérsias que emergiu foi a concomitância de argumentos e de reuniões. Essas controvérsias foram avaliadas quanto ao grau médio geral (quantidades de associações em cada nó). Paralelamente, identificamos nas entrevistas individuais e coletivas as controvérsias mais mencionadas. Comparadas as relações, emergiram quarenta controvérsias mais relevantes, que diferem em abrangência e tempo de desenvolvimento (Figura 4).

Por abrangência da controvérsia entendemos o rol de actantes envolvidos em três âmbitos sucessivamente maiores, a saber: UN ou CSC; Diretoria; e âmbito da Empresa X. Por sua vez, entendemos que o tempo de desenvolvimento da controvérsia é o decorrido a partir de seu início (embate inicial entre actantes com posições antagônicas) até o seu encerramento (prevalência de uma posição sobre as demais com cessação dos debates). 0 tempo de desenvolvimento considerado foi dividido em três períodos: curto prazo (até três meses); médio prazo (de quatro a doze meses); longo prazo (mas de um ano). 
Figura 4

\section{Controvérsias relevantes por abrangência e tempo de desenvolvimento}

\begin{tabular}{|c|c|c|c|c|}
\hline \multirow{5}{*}{ 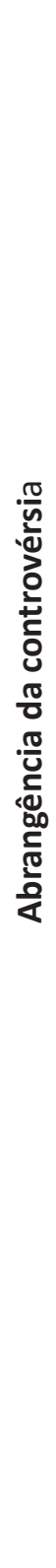 } & \multirow{2}{*}{ 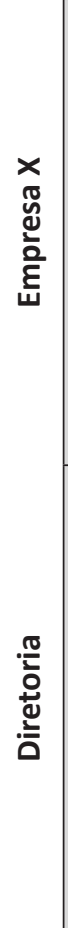 } & $\begin{array}{l}\text { - Participação do implementa- } \\
\text { dor na reunião da diretoria } \\
\text { colegiada } \\
\text { - Abordagem de implementa- } \\
\text { ção da mudança de big bang } \\
\text { - Aprovação proj CSC pela } \\
\text { diretoria colegiada }\end{array}$ & $\begin{array}{l}\text { - Apresentação do projeto para as } \\
\text { autoridades funcionais }\end{array}$ & $\begin{array}{l}\text { - Formalização da estrutura do CSC } \\
\text { - Problema dos gestores } \\
\text { - Regionalização do SESMT } \\
\text { - Modelo de sistemas organizacionais e de } \\
\text { autoridades funcionais } \\
\text { - Risco de assimilação do CSC pelas autorida- } \\
\text { des funcionais } \\
\text { - Extinção dos deptos adms } \\
\text { - Adoção do modelo CSC por outras diretorias } \\
\text { - Resultados do projeto CSC }\end{array}$ \\
\hline & & $\begin{array}{l}\text { - Definição dos limites de } \\
\text { atuação do implementador e } \\
\text { gerente do CSC } \\
\text { - Questão da onda financeira } \\
\text { - Solução de transição gerente } \\
\text { do CSC enquanto formaliza- } \\
\text { ção não ocorre } \\
\text { - Inclusão da implementação } \\
\text { CSC como macroação no } \\
\text { planejamento tático direto- } \\
\text { ria operação RMSP }\end{array}$ & $\begin{array}{l}\text { - Possibilidade de mudança do } \\
\text { diretor operação RMSP } \\
\text { - Definição do gerente do CSC } \\
\text { - Localização do CSC } \\
\text { - Questão do modelo de gestão } \\
\text { administrativa da diretoria }\end{array}$ & $\begin{array}{l}\text { - Método de dimensionamento de pessoal } \\
\text { - Mudança do papel dos deptos adms pós- } \\
\text { - Comunicação durante o projeto CSC } \\
\text { - Quadro de pessoal deptos adms } \\
\text { - Contratação de empregados adms } \\
\text { - Resistência dos Sups ao projeto CSC } \\
\text { - Cronograma do projeto implementação do } \\
\text { CSC } \\
\text { - Desempenho dos deptos adms }\end{array}$ \\
\hline & \multirow[t]{3}{*}{$\frac{z}{3}$} & & $\begin{array}{l}\text { - Segmentação atividades CSC x UN } \\
\text { - Segmentação atividades RH } \\
\text { - Segmentação atividades DH } \\
\text { - Concorrência entre CSC x UNs }\end{array}$ & $\begin{array}{l}\text { - Definição dos gestores do CSC } \\
\text { - Resistência dos gers adms à cessão de pes- } \\
\text { soas para o CSC } \\
\text { - Movimentações de pessoas no projeto CSC } \\
\text { - Clima nos adms por conta da mudança } \\
\text { - Desempenho da consultoria CSC } \\
\text { - Questão das transições pessoais } \\
\text { - Mapeamento de processos durante a fase de } \\
\text { implementação } \\
\text { - Sentimento de piora dos serviços prestados }\end{array}$ \\
\hline & & $\begin{array}{l}\text { Curto-prazo } \\
\text { (Até } 3 \text { meses) }\end{array}$ & \multirow{2}{*}{\multicolumn{2}{|c|}{ desenvolvimento da controvérsia }} \\
\hline & & Tempo d & & \\
\hline
\end{tabular}

Fonte: Elaborada pelos autores.

Legenda: Negrito: controvérsias encerradas (caixas-pretas).

As quarenta controvérsias consideradas mais relevantes estão dispersas tanto em termos de abrangência quanto em relação a seu tempo de maturação. Os debates se dão sobre temáticas que podem ficar praticamente restritas às UN e/ ou ao CSC, ou no âmbito da diretoria de operação, ou ainda no âmbito corporativo. Em relação à dimensão tempo, controvérsias tiveram maturação nos três períodos considerados. A área sombreada na referida figura corresponde às caixas-pretas, no prazo de um ano, de âmbito tanto da diretoria quanto da Empresa X. As controvérsias de longo prazo nos três âmbitos acabaram não sendo concluídas até o fim do período pesquisado. Salientamos que a ausência de registro de controvérsias do âmbito da UN/CSC de curto prazo não significa inexistência nesse período. Controvérsias existiram, 
porém, quando avaliada, a sua relevância, não foram encontrados debates significativos. Estavam entre as 190 controvérsias, mas não entre as 40 selecionadas.

Como já dissemos, na escala intermediária a dinamicidade social é aflorada por conta da sucessão de aparecimento e debate de diversas controvérsias, algumas das quais relacionadas entre si, sendo encerradas ou não, permeando as discussões (Figura 5).

Figura 5

\section{Controvérsias acumuladas durante todo o período analisado}

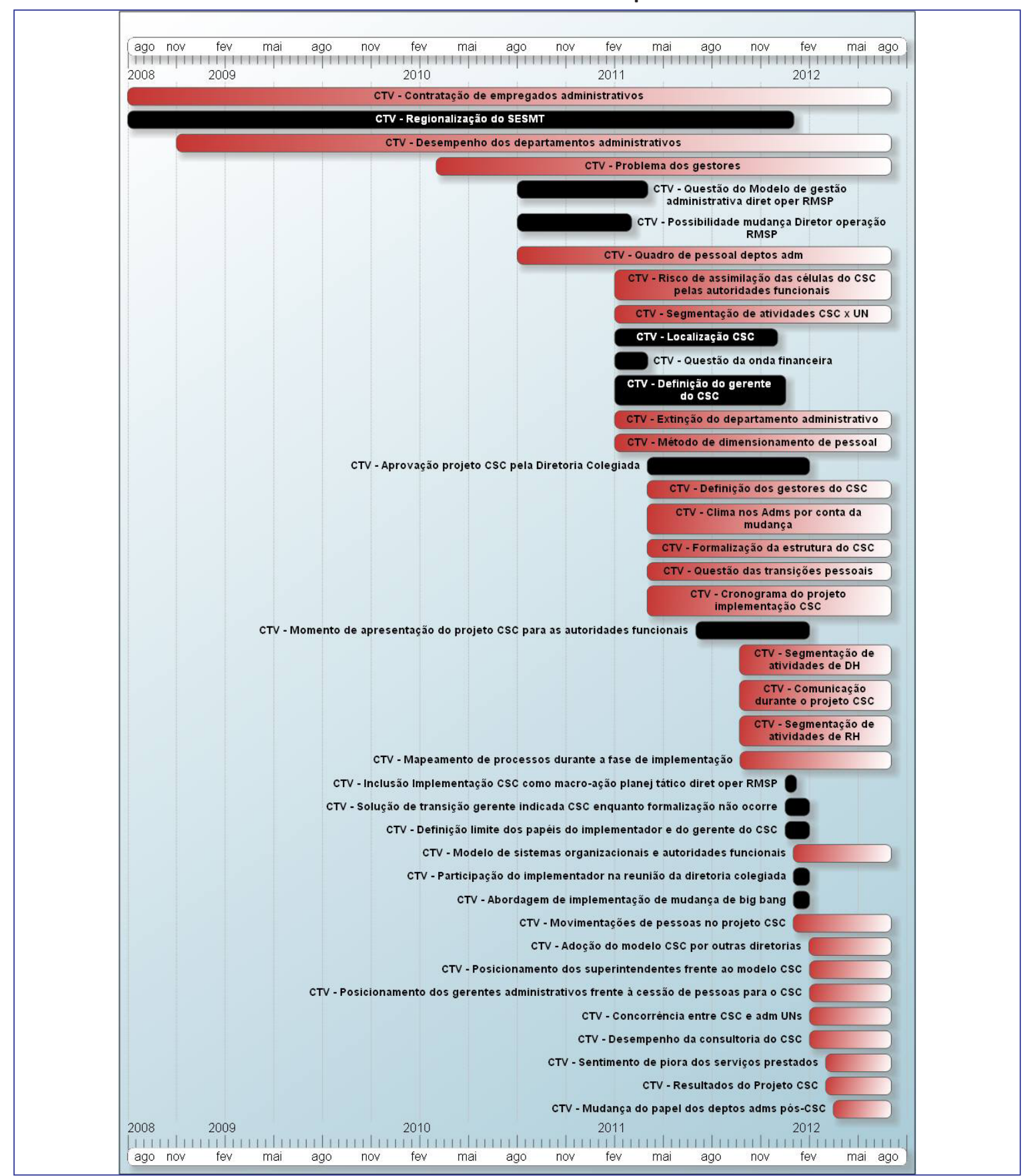

Fonte: Elaborada pelos autores. 
Nesses debates, os actantes se associaram em torno de posições diferentes nas controvérsias. Isso ficou claro ao analisar a participação dos actantes humanos na dinâmica social (pela quantidade de associações com demais elementos), pois alguns tiveram atuação central na dinâmica da translação. Foram eles: o diretor, o implementador, a gerente do CSC, o consultor e os gerentes administrativos.

Entretanto, a ação não ficou restrita a atores humanos. Certos actantes não humanos também tiveram ação mediadora, mudando o curso dos acontecimentos. Foi o caso dos e-mails de designação do implementador e da gerente do CSC, os arquivos em Power Point guiando o discurso dos apresentadores, estudos encerrados anos antes voltaram à baila com recomendações que exigiram refutação (como o relatório de uma consultoria de redução de custos que defendeu implementações em uma estratégia de big bang) e rascunhos ${ }^{9}$ que forneciam os aspectos mais relevantes das argumentações que comporiam as versões finais (como o rascunho do slide sobre os riscos empresariais da estratégia de big bang, trazido à baila pelo consultor do CSC, defendendo uma posição contrária, que seria incorporada a apresentações subsequentes). Planilhas Excel facilitaram o dimensionamento de pessoal tanto do CSC quanto dos departamentos administrativos das UN/Sups da diretoria de operação da RMSP. Grupos formais ou informais (como o colegiado de diretores, o fórum da diretoria e o fórum administrativo) ou ainda unidades organizacionais (como as Unidades de Negócio ou os departamentos administrativos), caracterizado à luz da ANT como macroatores ou atores-institucionais, alteraram a dinâmica social partindo de decisões por eles tomadas.

Como podemos observar, diversas controvérsias continuaram presentes no ambiente empresarial. Uma pergunta se apresenta: por que determinadas controvérsias se encerraram transformando-se em caixas-pretas e outras permaneceram "ativas"? Uma possível resposta pode estar associada ao relacionamento entre as próprias controvérsias (Figura 6).

\section{Figura 6}

\section{Relacionamentos entre controvérsias da translação em estudo}

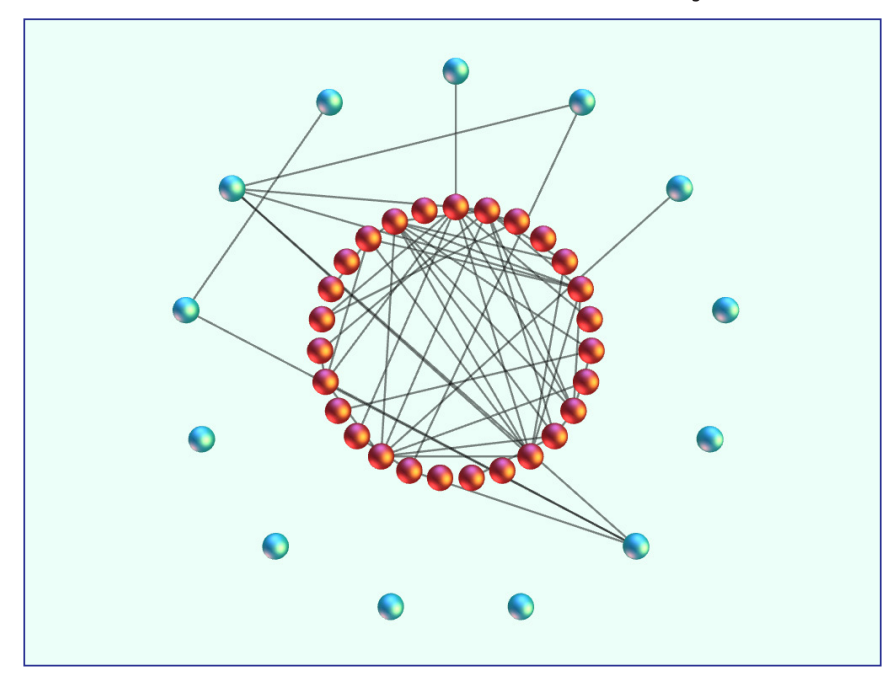

Fonte: Elaborada pelos autores.

Legenda: Controvérsia; Caixa-preta; associação entre controvérsias ou caixas-pretas.

Um olhar das associações por meio da distribuição dual circular lay-out (caixas-pretas no círculo externo e as controvérsias no interno) mostrou intenso relacionamento entre as controvérsias não encerradas e poucas associações entre as caixas-pretas (entre si e as controvérsias não encerradas). Tal situação sugeriu que a dificuldade de encerramento das controvérsias remanescentes seria devida à profusão de associações (Figura 6). Tal constatação sugere que em processos de mudança não existe estabilidade, mas, sim, um contínuo processo de constituição e pontualização de controvérsias.

Esses foram os únicos agentes ao longo de toda a translação? Uma análise mais profunda evidenciará que não. Para poder mostrar a agência desses outros actantes, precisamos de um olhar ainda mais próximo das controvérsias. É o que faremos no próximo tópico.

${ }^{9}$ Latour (2001) destacou a importância de rascunhos que tragam os elementos principais de um estudo. 


\section{Escala maior: por dentro da controvérsia e mais perto dos não humanos}

A escala maior é aquela em que procuramos ter um entendimento em profundidade das controvérsias e, por consequência, do processo de mudança em si, colocando uma lente na agência de humanos e não humanos. Visando a apresentar como uma controvérsia se desenvolve até se tornar uma caixa-preta, exemplificaremos detalhando duas controvérsias, a saber: a "inclusão da implementação do CSC como macroação do planejamento tático da diretoria de operação da RMSP" e a "definição do gerente do CSC". Ambas são de abrangência da diretoria, porém, a primeira demandou um único dia e a segunda, meses.

A controvérsia "inclusão da implementação do CSC como macroação do planejamento tático da diretoria de operação da RMSP" envolveu três posições inferidas: não incluir a macroação; incerteza quanto à inclusão da macroação; e incluir a macroação (Figura 7). Cada posição, em cada tema da controvérsia, é defendida por actantes humanos e não humanos.

Figura 7

Inclusão da implementação do CSC como macroação do planejamento tático da diretoria de operação da RMSP

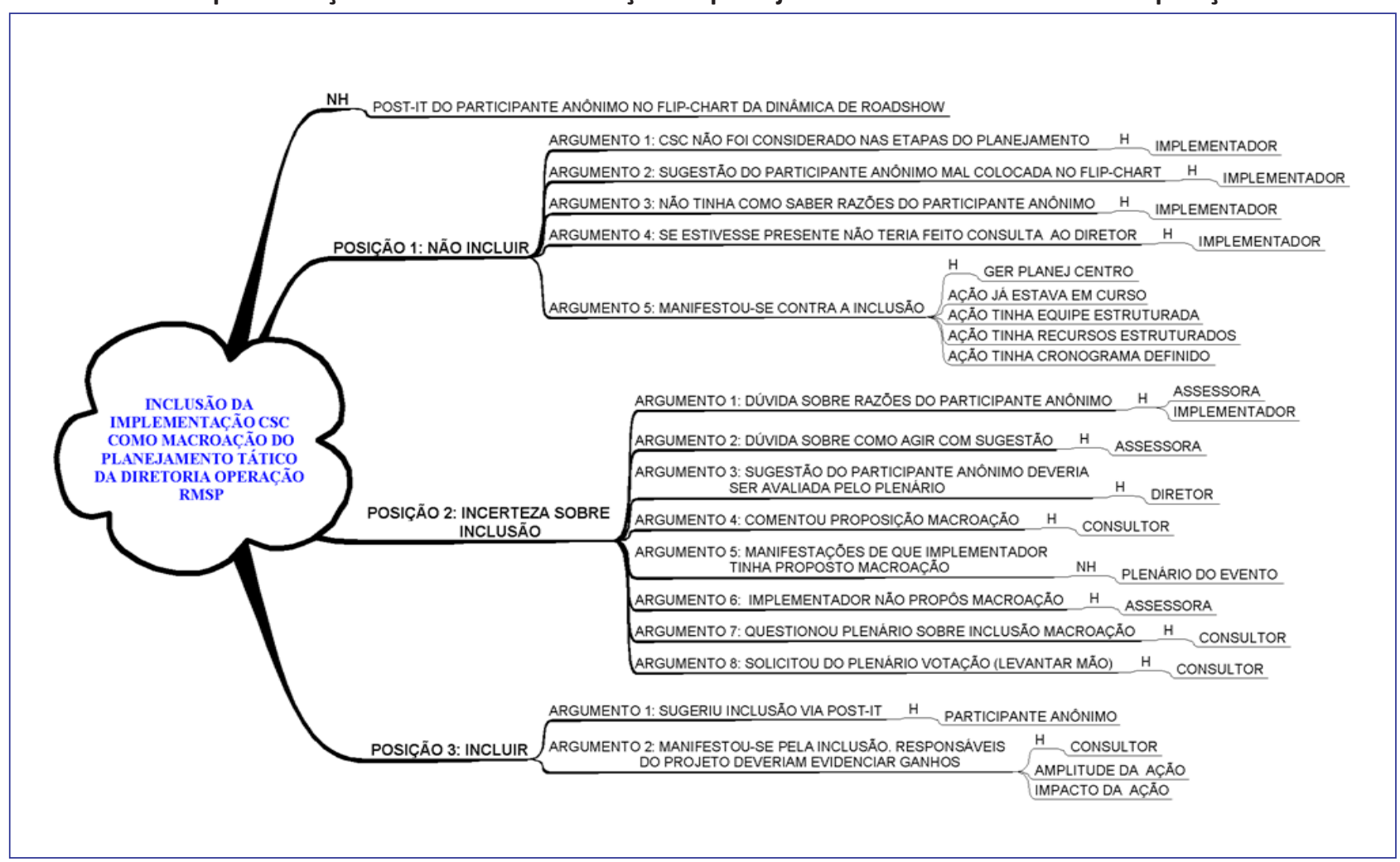

Fonte: Elaborada pelos autores.

O discurso oficial informava que na reunião do planejamento tático da diretoria de operação da RMSP o projeto de implementação do CSC foi incluído como macroação da diretoria, partindo do debate que aconteceu em plenária. No entanto, os acontecimentos foram muito mais complexos do que faz supor a descrição. Parte dos motivos que levaram à decisão tomada diz respeito a uma cadeia de coincidências e da agência de dois não humanos que "conspiraram" a favor da causa: um post-it e a lei de rodízio de placas (Quadro 1$)^{10}$.

${ }^{10}$ A Lei n. 12.490, de 03/10/1997, implantou o programa de restrição ao trânsito de veículos automotores no município de São Paulo. Em síntese, estabeleceu que os veículos de determinados finais de placa em dias da semana definidos não poderiam circular das $7 \mathrm{~h}$ às $20 \mathrm{~h}$ na região central e em uma área delimitada. 


\section{Quadro 1}

\section{A conspiração do post-it ${ }^{\circledast}$ com a lei municipal de rodízio}

\begin{tabular}{|c|c|}
\hline Descrição dos acontecimentos & Um olhar da ANT \\
\hline 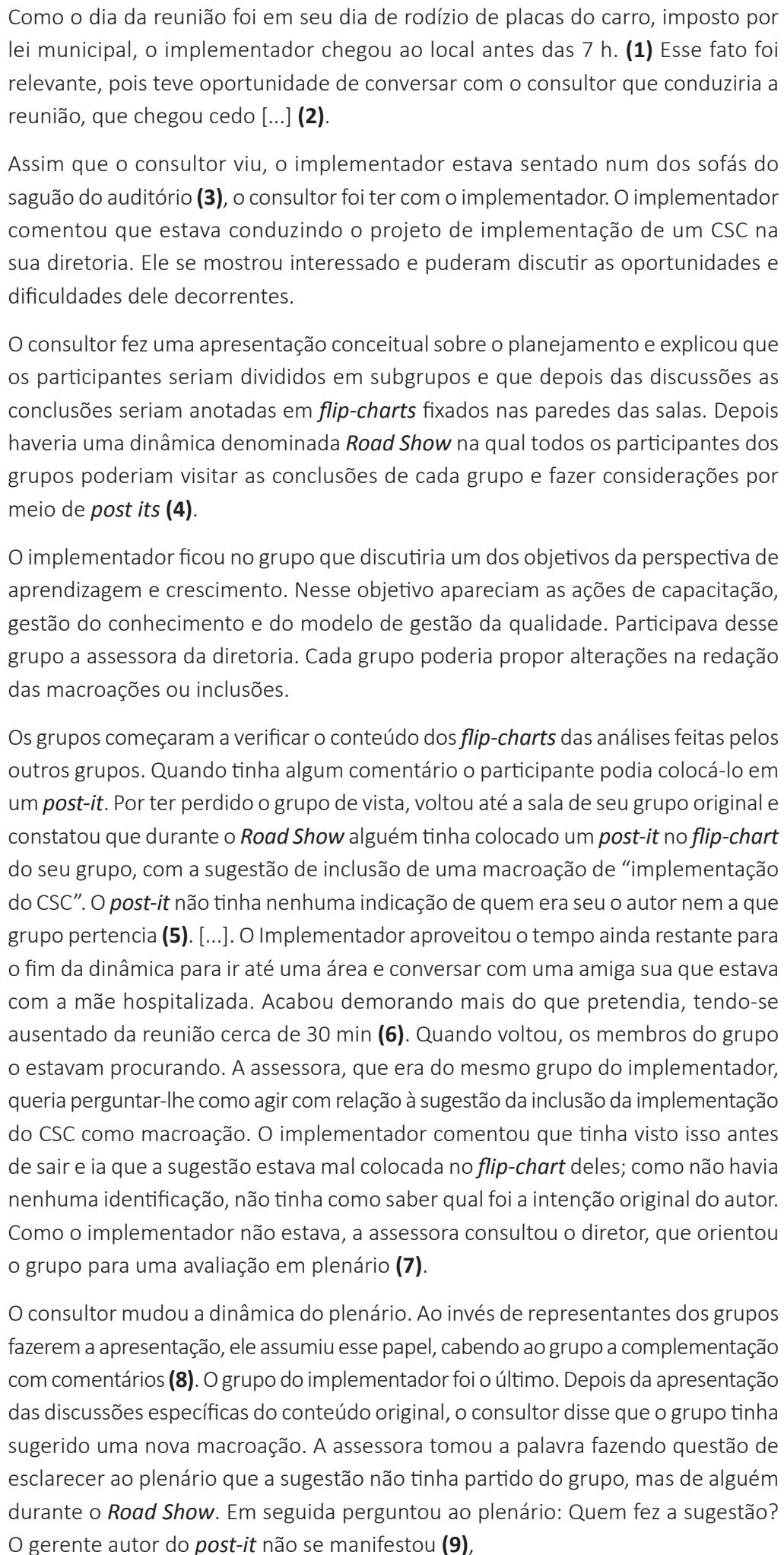 & $\begin{array}{l}\text { (1) A lei do rodízio (não humano) fez o } \\
\text { implementador chegar antes das 7h. } \\
\text { (2) Não fosse a lei do rodízio o } \\
\text { implementador não teria tido a } \\
\text { oportunidade de conversar com o } \\
\text { consultor antes de a reunião começar. } \\
\text { (3) Os sofás (não humanos) permitiram } \\
\text { o encontro. } \\
\text { (4) Dois objetos (flip-chart e post-its) } \\
\text { e um quase objeto (dinâmica do Road } \\
\text { Show) criaram condições para que } \\
\text { alguém expressasse sua opinião. } \\
\text { (5) A dinâmica permitiu que alguém se } \\
\text { manifestasse por meio de um post-it. } \\
\text { Como a pessoa não se identificou, o } \\
\text { post-it agiu por si. } \\
\text { (6) A hospitalização foi uma coincidência } \\
\text { que tirou da discussão sobre a } \\
\text { pertinência do post-it o implementador } \\
\text { num momento decisivo, já que tinha } \\
\text { se manifestado contrariamente à } \\
\text { proposta constante no post-it. Sem o } \\
\text { implementador para "atrapalhar", o } \\
\text { post-it pôde agir sozinho. } \\
\text { (7) O plenário é um ator-institucional } \\
\text { despersonalizado dos actantes humanos } \\
\text { que o constituem. } \\
\text { (8) A nova dinâmica (um quase objeto) } \\
\text { deu mais voz ao consultor, permitindo } \\
\text { a interação com o auditório a partir } \\
\text { do conhecimento prévio sobre o } \\
\text { proje post-it. }\end{array}$ \\
\hline
\end{tabular}




\begin{tabular}{|c|c|}
\hline Descrição dos acontecimentos & Um olhar da ANT \\
\hline $\begin{array}{l}\text { O consultor tomou a palavra e questionou o plenário sobre o que achavam da } \\
\text { sugestão surgida no Road Show. Um gerente de departamento [...] afirmou que } \\
\text { achava que não deveria haver uma macroação já que era uma ação que já estava } \\
\text { em pleno curso, com equipe e recursos estruturados e cronograma definido e em } \\
\text { implementação (10). Então o consultor disse que entendia que uma ação tão ampla } \\
\text { e impactante como essa mereceria ser acompanhada. Em seguida questionou o } \\
\text { plenário se deveriam incluir ou não o projeto como macroação levantando a mão. } \\
\text { Mais da metade dos presentes levantou a mão, entre eles o diretor (11). Dessa } \\
\text { forma a implementação do CSC foi estabelecida como uma macroação [...]. }\end{array}$ & $\begin{array}{l}\text { (10) O gerente caracterizou outro quase } \\
\text { objeto, o projeto CSC. } \\
\text { (11) Aqui a dinâmica proposta (votação } \\
\text { com as mãos) cumpriu um papel na } \\
\text { indução coletiva. A votação do diretor } \\
\text { pode ter estimulado os indecisos. }\end{array}$ \\
\hline
\end{tabular}

Fonte: Elaborado pelos autores mediante diário do projeto.

Como pode ser observado no relato, o discurso oficial não revela as nuances da agência de certos objetos (placas do carro do implementador, sofá, flip-chart e post-it) e quase objetos (lei de rodízio de placas, post-it manuscrito com a proposta, as dinâmica de Road Show, de apresentação de trabalhos, de votação e o próprio projeto CSC) alteraram o curso das ações. Portanto, a implementação do CSC acabou sendo incluída como uma macroação do planejamento tático da diretoria, porém, diversos outros elementos, alguns deles fora da Empresa X (como a lei de rodízios), influíram nessa inserção.

Outros actantes não humanos tiveram atuação decisiva em outras controvérsias. Uma rápida observação na segunda controvérsia descrita, definição do gerente do CSC, evidencia uma quantidade de actantes e de argumentos significativamente maior que a controvérsia anteriormente detalhada. Parte dessa complexidade deve-se aos nove meses decorridos entre seu início e seu encerramento (Figura 8).

\section{Figura 8}

\section{Controvérsia definição do gerente do CSC}

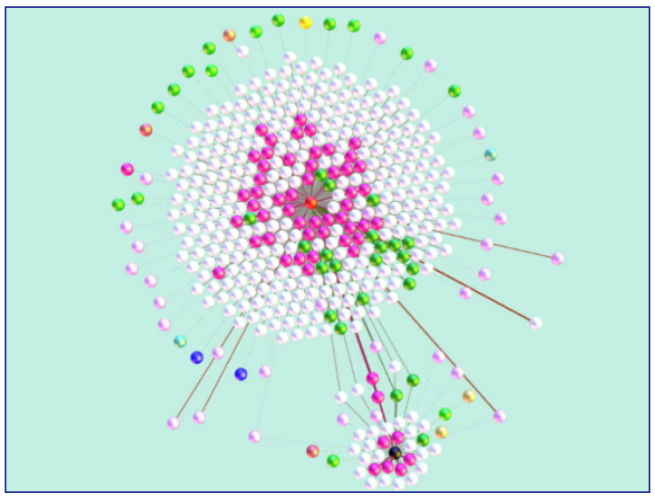

Fonte: Elaborada pelos autores.

Legenda: Nó vermelho: controvérsia de definição do gerente do CSC; Nós liláses: reuniões nas quais foi debatida a controvérsia; Nós brancos: argumentos usados pelos actantes durante os debates; Nós cor-de-rosa: actantes-humanos que participaram dos debates; Nós verdes: actantes-quase objetos envolvidos nos debates; Nós amarelos: actantes objeto envolvidos nos debates; Nó preto: caixa preta de definição do CSC; e Nó azul-claro: decisão de escolha do gerente do CSC.

O desenvolvimento da controvérsia pode ser entendido em três períodos distintos: (a) inauguração da controvérsia com a aprovação do projeto CSC. Nesse período a controvérsia foi sistematicamente exposta em reuniões que objetivavam 
esclarecer as dúvidas sobre o projeto. Alguns argumentos foram desenvolvidos nesses debates (Figura 9); (b) de abril a setembro de 2011, foi marcado pela ausência de apoio da consultoria por conta do processo licitatório em curso. Apesar de cogitações não havia expectativa de definição do gerente a curto prazo. A partir da contratação da consultoria, as discussões se intensificaram (Figura 10); (c) Com a escolha, surge a caixa-preta, encerrando a controvérsia (Figura 11).

Figura 9

Início da controvérsia

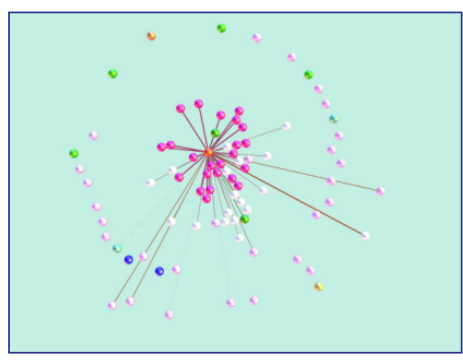

Fonte: Elaborada pelos autores.
Figura 10

Intensificação dos debates

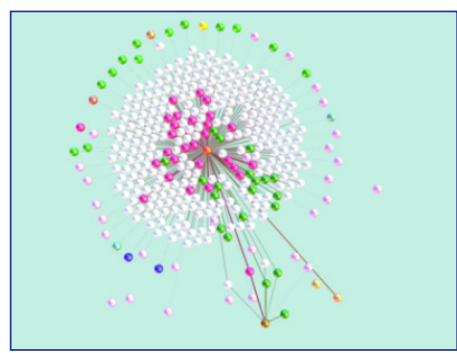

Fonte: Elaborada pelos autores.
Figura 11

\section{Após a caixa-preta}

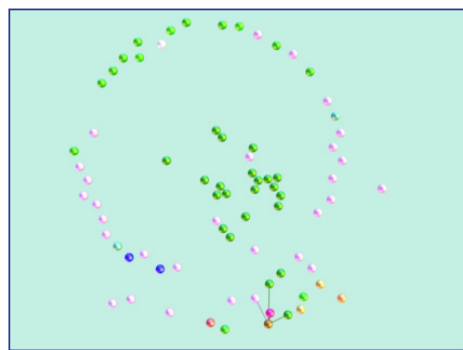

Fonte: Elaborada pelos autores.

Caso o leitor acesse o link indicado abaixo, terá oportunidade de observar o desenrolar dessa controvérsia desde seu aparecimento até seu encerramento:

<https://drive.google.com/file/d/OBxfyYI2ztV_IT2NZTWFpVGdITWs/edit?usp=sharing>

No início, os actantes humanos (nós cor-de-rosa) e não humanos (nós verdes) estão dispersos no plasma social. Nesse olhar, nada aparentemente os une. De repente, surge a controvérsia (representada pelo nó vermelho). Como um coração pulsando, os argumentos dos actantes passam a fazer parte da dinâmica social. Debates mais intensos são indicados com uma profusão de argumentos. Debates de menor intensidade acabam envolvendo um menor número deles. Em um dado momento, ocorre uma redução drástica da dinâmica observada, com o surgimento da caixa-preta depois da tomada de decisão pelo diretor, definindo quem assumiria a gerência do CSC.

Além da dinamicidade social mencionada, a controvérsia de definição do gerente do CSC contou com a participação ativa de diversos actantes humanos e não humanos. Para se ter uma ideia da diversidade de actantes envolvidos, descrevemos os acontecimentos em uma das reuniões do fórum dos gerentes administrativos (Quadro 2).

\section{Quadro 2}

\section{Diretor escolhe diretamente o gerente do CSC ou o processo seria assistido}

\section{Descrição dos acontecimentos}

O consultor comentou que a pauta daquela reunião (1) tinha como tópicos principais os assuntos tratados na reunião com o diretor [...]. Em seguida passou a palavra ao implementador para que fizesse um relato sobre a reunião com o diretor. [...] O implementador disse que o diretor não tinha ainda clareza quanto ao perfil daquele que deveria assumir a posição de gerente do CSC (2). O implementador comentou que a consultoria tinha apresentado um rol de requisitos para o ocupante do cargo (3) e que conhecia gestores das áreas que teriam possibilidade de gerenciar uma área como essa, porém que não conhecia todos. [...] Consultor e implementador propuseram usar o método do perfil psicológico (4) para subsidiá-lo na escolha, pois era uma metodologia consagrada na diretoria [...]. O diretor concordou com o uso do método.

Um olhar da ANT

(1) A pauta da reunião guiou o consultor.

(2) A posição de gerente do CSC é um não humano que passou a permear as discussões.

(3) Os requisitos do cargo são características do não humano "posição do gerente do CSC".

(4) O método do perfil psicológico é outro não humano que goza de prestígio na Empresa X. 


\section{Descrição dos acontecimentos}

O implementador informou que tinha pedido auxílio à gestora de DH Sul [...]. A gestora apresentou os conceitos adotados na avaliação do perfil psicológico, a forma como cada avaliado era percebido naquele papel e o esforço de adequação (5). Portanto, o que era observado pelos outros resultava de um esforço de adaptação do avaliado e não o que a pessoa efetivamente seria. Dessa forma, precisaríamos ter tanto o perfil dos candidatos a gerente quanto o perfil ideal para o cargo (6). Como a maioria dos gerentes e gestores já tinha o perfil psicológico levantado, essa parte demandaria pouco esforço. Por sua vez, o perfil ideal poderia ser definido por dois métodos: presencial ou web. O presencial era obtido por uma reunião prévia com fechamento. O perfil via Web seria enviado em um link via e-mail, que poderia ser preenchido diretamente no sistema da consultoria do perfil psicológico (7) e, posteriormente, se necessário, poderia haver uma reunião de fechamento. [...].

A gestora de DH Sul passou a questionar quem seriam as pessoas que teriam seu perfil avaliado e contrastado com o perfil psicológico ideal para que pudesse verificar na consultoria do perfil psicológico se essa já tinha os perfis anteriormente levantados ou se precisariam ser avaliados (8). [...] Nesse momento, o consultor sugeriu que cada gerente indicasse um ou dois gestores de seus quadros para concorrer. [...] O gerente administrativo Sul comentou que poderíamos discutir os nomes e se poderia votar no gestor de outra área. O implementador questionou se isso seria válido. Se já era difícil indicar alguém da própria equipe, quanto mais de outras áreas. A gerente administrativa Centro disse que se sentia desconfortável para indicar um ou dois, pois poderia depois ser questionada sobre qual critério teria seguido (9). Além do mais, havia gestores que não poderiam concorrer por estarem em cargos técnicos e não universitários [por restrição constitucional do plano de cargos e salários (PCS) (10)]

[...] o implementador questionou a gestora de DH Sul sobre qual seria a dificuldade de usar o perfil psicológico de todos os gestores e dos gerentes administrativos. Ela afirmou que não haveria nenhuma dificuldade já que o processo seria por confrontação de perfis calculados pelo programa (11) Além do mais, poderiam ser listados os perfis ideais e os aproximados [...]. Portanto, decidiu-se que todos os gestores participariam do processo. Dessa forma restava saber quais gestores atuais não tinham perfis levantados. Ficou acordado que cada gerente de departamento enviaria para a gestora a relação dos respectivos gestores para que ela verificasse junto à consultoria do perfil psicológico a disponibilidade ou não do perfil. Dessa forma, quem não tivesse o perfil levantado teria de fazê-lo (12). Os gerentes também receberiam um e-mail com o link (13) para estruturar o perfil psicológico ideal do gerente do CSC. O consultor perguntou se seria possível receber um link [...], assim como apontou a importância do diretor participar [...]

(14). A gestora afirmou que não haveria problema.
Um olhar da ANT

(5) O método do perfil psicológico é constituído por humanos e não humanos.

(6) O perfil psicológico ideal é um não humano resultante da construção coletiva.

(7) O método inclui outros não humanos (software, link, e-mail) ampliando a rede.

(8) O processo de escolha passou a discutir o envolvimento de humanos (gestores) e de não humanos (relatório dos perfis psicológicos).

(9) A preocupação da gerente administrativa Centro foi se seria questionada sobre o critério que teria adotado, também um não humano.

(10) O PCS e a Constituição federal são não humanos que impedem certos gestores a serem considerados para a gerência do CSC.

(11) Uma controvérsia pontual que havia se estabelecido foi sanada pela capacidade do software (não humano) de tratar grandes volumes de dados, permitindo a participação de todos no processo seletivo.

(12) Não foi discutido há quanto tempo os perfis psicológicos tinham sido levantados (suposta invariância no tempo) ou se ocorreram problemas na sua construção (caixas-pretas).

(13) Os não humanos seriam materializados nos dias subsequentes.

(14) O perfil psicológico ideal é um ator-rede constituído de método, gerentes, consultor e diretor.

Fonte: Elaborado pelos autores.

As duas controvérsias detalhadas na escala maior vieram a se agregar às demais caixas-pretas anteriormente encerradas, dando mais um passo no processo de estabilização do CSC. 


\section{À GUISA DE DISCUSSÃO E ENCERRAMENTO}

Neste artigo, objetivamos compreender como a agência de não humanos e humanos e a agência de sua associação ocorre em processos de mudança de foco não tecnológico em uma empresa à luz da ANT. Para tanto, estudamos a implantação de um Centro de Serviços Compartilhados em uma empresa paulista de economia mista.

A implementação de um CSC que, de uma perspectiva episódica, seria considerado um processo planejado em resposta a demandas do ambiente externo e/ou interno, como a busca das melhores práticas de mercado e a redução de custos, tem diferentes contornos quando analisado como uma mudança contínua à luz da ANT. Nessa ótica a implementação do CSC é o resultado da estabilização precária de redes envolvendo atores/actantes de diferentes materialidades e temporalidades, ideias e pontos de vista diversos (CZARNIAWSKA, 2008), além de interesses muitas vezes conflitantes (VENTURINI, 2010a), distribuídos, neste estudo, em quase duas centenas de controvérsias.

Investigando com o olhar de "lupa" exigido pela Teoria Ator-Rede, seguindo incansavelmente actantes humanos e não humanos para obter diferentes pontos de vista, mediante vários meios de levantamento de dados (VENTURINI, 2010a), foi possível observá-los ao se envolverem em quarenta controvérsias mais significativas. No fim de catorze meses de pesquisa, apenas treze controvérsias haviam sido traduzidas em caixas-pretas. Depois do encerramento da observação participante, em 30/06/2013, o CSC não havia se tornado uma caixa-preta, pois as 27 controvérsias em debate à época continuaram sem definição. Apesar disso, o processo de implementação teve continuidade, tendo sido a 2ạa a 3 a e a 4a ondas implementadas. A 5a onda não tinha acontecido até novembro de 2015. Por sua vez, nenhuma caixa-preta foi reaberta.

Retornando ao foco deste estudo - a questão da agência de humanos e não humanos e da sua associação, a constatação da agência dos humanos não constituiu uma dificuldade. Na translação estudada, ficaram no centro do palco quatro personagens humanos que interagiram com os demais actantes (humanos e não humanos) identificados. Foram eles: o diretor da RMSP, o implementador, a gerente do CSC e o consultor do CSC. Além desses, foram observadas diversas ações tomadas por outros actantes humanos, que também atuaram como mediadores nas redes formadas. Essa agência ocorreu, por exemplo, na participação ativa em debates, apresentando argumentos geradores de controvérsias e na tomada de decisões.

Pudemos depreender do estudo de caso que três posturas típicas foram observadas, a saber: (a) Debatedores: alguns actantes se mostraram defensores ferrenhos de certas posições em determinadas controvérsias; (b) Facilitadores: outros actantes, apesar de também ter suas posições, acabaram assumindo postura de facilitação dos debates, fazendo que as diversas posições sejam explicitadas em prol de um debate mais profícuo. Durante o transcorrer dos acontecimentos, tanto o implementador quanto o consultor do CSC assumiram preponderantemente essa postura; (c) Decisores: outros actantes, além de participar dos debates tinham o papel de tomadores de decisão, escolhendo qual posição seria a mais adequada, em sua ótica, contribuindo parcial ou decisivamente para o fechamento das controvérsias, transformando-as em caixas-pretas. Na maioria das situações, tais decisões foram tomadas pelo diretor de operação da RMSP e pela gerente do CSC.

Salientamos que tais posições não foram exclusivas de actantes humanos. Não humanos também assumiram ações equivalentes. $O$ debate com um não humano pode ser observado nos contrapontos que foram feitos ao relatório da consultoria de redução de custos, ao defender implementações em uma estratégia de big bang. Portanto, um não humano estava defendendo determinada posição no debate. Outro não humano - o slide sobre os riscos empresariais da estratégia de big bang - trazido à baila pelo consultor do CSC acabou defendendo uma posição contrária. A postura de facilitador também pode ser observada em determinados não humanos. Foi o caso das planilhas de dimensionamento de pessoal que facilitaram o debate sobre o número de pessoas que deveria compor o CSC e os departamentos administrativos nas UN/ Sups. Finalmente, certos não humanos tiveram postura decisória. Isso aconteceu no caso dos atores-institucionais, vistos aqui como pontualizações de atores-redes, que acabaram por decidir o curso de determinadas ações, como da diretoria colegiada aprovando a continuidade da implementação do projeto CSC.

Portanto, a agência de não humanos também pôde ser observada ao longo do estudo. Para tanto, tivemos de adotar o princípio da simetria, preconizado por Latour (1994), de forma a estar atentos à ação dos não humanos na dinâmica social 
não apenas como resultado da ação humana. Apesar de mais discretos, não humanos mostraram-se atuantes, mediando as associações deles com outros actantes, agindo e alterando o curso dos acontecimentos.

Em síntese, atuaram na concepção de Latour (2005), como "mediadores", agindo de diferentes formas: (a) sugeriram a inclusão do CSC no planejamento tático da diretoria (no caso do post-it); (b) apontaram qual seria o perfil psicológico adequado para a gerência do CSC e selecionaram os candidatos mais aderentes a esse perfil; (c) determinaram o que deveria ou não ser feito (no caso dos contratos com as consultorias); (d) apresentaram razões para elaboração, recordaram aspectos históricos, levantaram situações vigentes, discutiram possibilidades de solução e recomendaram cursos de ação (no caso, por exemplo, dos estudos de consultorias); (e) alertaram sobre o risco empresarial de abordagens precipitadas de mudança (slide sobre estratégia de implementação de big bang ou por ondas), diferenciaram a centralização da descentralização e do CSC (slide sobre diferença dos modelos organizacionais) e segmentaram atividades (slide de segmentação de atividades CSC versus departamentos administrativos). Estas e outras agências dos não humanos encontram eco nas considerações de Latour (2005, p. 72), quando afirmou que "[ao invés de] determinar e servir como um pano de fundo para a ação humana, as coisas podem autorizar, permitir, produzir, encorajar, sugerir, influenciar, bloquear, retribuir, proibir, e assim por diante".

Alguém pode alegar que tais não humanos foram concebidos por actantes humanos e, portanto, tais ações eram intenções dos "autores" originais. A questão não é a origem, nem a intenção original do autor e, sim, a ação do não humano, independentemente de seu "criador". Essa ação pode acontecer, apesar da ausência de quem o concebeu (e em alguns casos sem saber quem o concebeu). Outro ponto é se essa ação estará ou não alinhada às intenções originais do autor, pois um não humano pode estimular reações diversas das pretendidas.

Além das agências de humanos e não humanos, o estudo identificou a agência da associação de humanos e não humanos. Como visto anteriormente, actantes humanos como atores-rede resultam da associação de humanos e não humanos, mas também actantes não humanos podem ser atores-redes que têm em sua constituição humanos. Isso deve ter ficado particularmente claro na descrição do processo de escolha da gerente do CSC. Para a constituição do ator-rede "gerente do CSC" concorreram diversos humanos e não humanos. Entre os actantes humanos foram envolvidos os gerentes e gestores administrativos, os consultores do CSC e do perfil psicológico, a assessora, o implementador e o seu superior original, o superintendente de Produção B, que concordou com a liberação da sua gerente administrativa para assumir o CSC. Por sua vez, os não humanos particularmente relevantes na constituição do ator-rede gerente do CSC foram o método do perfil psicológico, os relatórios de perfis psicológicos dos candidatos e o e-mail de designação. Quando deu início à gestão do CSC esse ator-rede foi se associando a cada um dos membros das equipes que foram se formando à medida que cada onda do processo de implementação caminhava, com os superintendentes e gerentes administrativos e a infraestrutura do CSC. Portanto, a capacidade de agência desse ator-rede decorre da associação desses actantes que participaram na fase de sua escolha (pontualizados em uma caixa-preta). Este não foi um caso único. São exemplos de situações similares às redes que constituíram o implementador e o projeto CSC.

O conceito de plasma da ANT, ou seja, todos os humanos e não humanos que não participaram da dinâmica social (LATOUR, 2005), também apareceu neste estudo, estando presente desde o início e modificando-se no transcorrer de desenvolvimento da dinâmica social. Isso ocorreu por conta de alguns actantes terem deixado de se associar com outros na rede da implementação do CSC. Por sua vez, actantes que pertenciam ao plasma vieram a se agregar à dinâmica social da referida implementação, pois passaram a se associar à rede. Isso também não se restringiu aos actantes humanos, havendo diversos não humanos que igualmente se desassociaram ou se agregaram à rede do CSC.

Além da agência de humanos e não humanos e de sua associação, a adoção da Teoria Ator-Rede nos permitiu compreender a complexidade da mudança como fluxo, como construção de controvérsias decorrentes dos interesses conflitantes de actantes. Algumas controvérsias, ao se estabilizar, organizam esse fluxo e resultam em algo aparentemente estável, ou seja, levam à "organização", como é o caso do CSC, caso se transforme em uma caixa-preta. Todavia, é importante sublinhar que, mesmo que isso aconteça, as redes envolvidas nas controvérsias encerram, em suas associações, diferentes posições e argumentos que as constituem, possibilidades que podem ser retomadas pelos actantes a qualquer momento, gerando outras translações/traduções, em um contínuo processo de organizar (organizing) ou tornar-se (becoming). 
À luz da ANT, fica mais claro visualizar o que observou Chia (1999, p. 223, tradução nossa) ao defender uma ontologia de processos (na qualidade de fluxo) para mudança: "já não podemos traçar uma única trajetória ao longo da qual a mudança irá ocorrer. Em vez disso, agora precisamos pensar em termos de múltiplas trajetórias de grupos de probabilidade", ressaltando o aspecto imprevisível da mudança nas organizações. Mackay e Chia (2013) mostram que acaso, escolhas e consequências não antecipadas, sobre as quais gestores não têm controle, são capazes, quando associados, de levar a trajetórias muito diferentes das imaginadas. Nesse sentido, podemos lembrar as "coincidências" relatadas na controvérsia da "inclusão da implementação do CSC como macroação do planejamento tático da diretoria de operação da RMSP", quando a saída do implementador da sala onde estava ocorrendo o evento, o rodízio municipal e o post-it elevaram o CSC a uma ação da estratégia da empresa, ultrapassando a diretoria que a propôs. Esse é apenas um exemplo de outros tantos eventos com complexidades maiores ou menores que permitem exemplificar o que Chia (2014) e Mackay e Chia (2013) querem dizer sobre processos sem dono (unowned).

É possível mostrar que a tradução dos interesses de atores-rede em um Centro de Serviços Compartilhados, mediante a construção de argumentos e posições, é algo que se dá de forma dinâmica, diferentemente do que querem nos fazer acreditar a literatura sobre o tema. Livros de referência sobre a implantação de Centros de Serviços Compartilhados ( $p$. ex., BERGERON, 2003; SCHULMAN, DUNLEAVY, HARMER et al., 1999) nos colocam a perseguir os tão conhecidos "fatores críticos de sucesso" como se fossem valer para sempre. Um CSC, ou a "simples" definição de quem irá administrá-lo, como ilustrado neste artigo, não é algo posto, mas, sim, consequência de eventos que não conhecemos a priori. 0 gerente do CSC é um ator-rede e só terá essa identidade enquanto certos actantes humanos e não humanos, inclusive argumentos traduzidos em posições "vencedoras", estiverem agregados.

A análise segundo uma ontologia de fluxo adotando a ANT colocou-nos diante do desafio de apresentar a descrição de como as coisas acontecem como fluxo de associações. Neste artigo, tratamos de ilustrar como isso pode ser feito. Observamos que essa tarefa se torna ainda mais desafiante na Teoria Ator-Rede, uma vez que não há a possibilidade de explicação, mas apenas sua pura descrição. Se algo tem de ser explicado, isto é, tem de ser apresentado como algo subjacente ao que foi descrito, é porque os pesquisadores não foram suficientemente ants para seguir os actantes (LATOUR, 2005) e mapear suas associações.

Mostrar a construção do social como fluxo magmático (VENTURINI, 2010a) torna-se viável, caso não desconsideremos os avanços da tecnologia de mídia com soluções inovadoras e criativas para ser adotadas pelo mundo acadêmico. Caso a mídia primária não seja papel, pesquisadores-ants podem considerar a inserção de vídeos no corpo do texto, permitindo a visualização dos resultados das pesquisas de forma dinâmica mediante hiperlinks. Essa e outras possibilidades, como a construção de portais na internet para apresentação de estudos baseados em cartografia de controvérsias (VENTURINI, 2010b), parecem mais bem-vindas e adequadas do que simplesmente passar a usar modelos de variância em organizing, como defendido por Van de Ven e Poole (2005).

Para encerrar este artigo, voltamos a seu início e à questão da gestão de mudança, tão cara aos administradores. A literatura em gestão faz parecer que gerir a mudança se assemelha a fazer o planejamento de uma rota para um avião: sabe-se que turbulências podem ocorrer, mas, se houver pilotos competentes para fazer os desvios necessários, chegar-se-á ao destino definido; os aviões seriam artefatos, meras máquinas voadoras à mercê dos bem treinados humanos.

No entanto, Grey (2004), entre outros autores já citados neste artigo, mencionava situações relativas a projetos de qualidade total e de reengenharia de processos que, em sua maioria, redundaram no fracasso em atingir seus objetivos. Portanto, entendemos que outras metáforas possam ser usadas visando à compreensão de como as coisas ocorrem nas empresas com base em uma ontologia de fluxo, por exemplo, o rafting.

Um grupo de pessoas enfrentando um rio caudaloso com inúmeras corredeiras. Por mais que haja alguém mais experiente, todos se associam para seguir um curso rio abaixo. Para tal precisam de equipamentos para a navegação e para sua proteção individual. Esses não são, contudo, os únicos não humanos envolvidos na situação. No caminho, além da turbulência das corredeiras, surgem pedras, cascatas, redemoinhos, curvas, cada qual exigindo ações distintas e, por vezes, inesperadas, que precisam ser superadas tão logo se apresentem. A possibilidade de o barco virar antes mesmo de chegar à parte calma do rio (se houver) e não atingir seu "destino" (como ocorreu com as vieiras estudadas por Callon) é significativa. 
A possibilidade de agência pontual em uma dinâmica social com "vida" própria encontra eco na visão proposta por Chia (2014) de processos "sem dono" (unowned). Ao considerar a profusão de actantes humanos e não humanos associando-se e desassociando-se continuamente, em controvérsias que surgem e se encerram, evidencia a impossibilidade de controle sobre a maioria desses elementos. Apenas nos alistamentos de actantes (processos ativos de associação) e nas decisões que redundem no encerramento de controvérsias (formação de caixas-pretas) é que intervenções pontuais podem ser levadas a efeito. Por sua vez, a intervenção humana em si correspondeu a apenas uma parcela da dinâmica observada por um pesquisador-ant (e muito menor ainda se considerado tudo que ficou por observar).

Portanto, o contínuo fluxo magmático venturiano das controvérsias e dos demais elementos dele participantes (actantes humanos, não humanos, suas associações, suas agências, os argumentos e as decisões) constituem um processo "sem dono", no qual a implementação do CSC na Empresa X foi apenas uma parte em que nos detivemos. O olhar para as controvérsias possibilitou a identificação de algumas oportunidades de agência de humanos e não humanos, assim como da agência de suas associações para intervenções pontuais na dinâmica social, que propiciaram a formação de determinadas caixas-pretas. Entretanto, a maior parte da dinâmica observada acabou "[se] deixando acontecer" (letting happen) já que tinham um mote próprio e invariavelmente imprevisível. Mesmo naquelas oportunidades que foram previamente identificadas (como as controvérsias que permaneceram ativas depois do término da construção dos dados) as intervenções para sua resolução restaram infrutíferas (debates inconclusivos em diferentes reuniões), pois tinham tempos de maturação e características que impediram seu encerramento (como as associações com outras controvérsias ativas ou já encerradas). Portanto, acabaram levando à indeterminação de se tais controvérsias poderiam vir a constituir caixas-pretas.

Portanto, ao invés dos administradores(-redes) fazerem gestão de mudanças, quando muito, podem procurar alistar actantes para "perseguir" objetivos alinhados com seus interesses. Entretanto, não há como garantir nem que os actantes alistados sigam o curso das ações desejado, nem como evitar que outros actantes não alistados e, por vezes, não vislumbrados, venham a se agregar à dinâmica social, fazendo que seus interesses originais não sejam atendidos, caixas-pretas sejam abertas, posições conflitantes ganhem adeptos e translações não previstas ocorram. Portanto, o destino final é uma incógnita, um vir a ser.

Então, nenhuma "gestão" é possível? O que fazer nas empresas se, na prática, projetos têm de ser feitos e serviços executados, ou seja, o social continuará demandando sua construção?

Entendemos que o arcabouço metodológico adotado neste projeto não teria condições de ser usado plenamente no âmbito empresarial por conta do esforço de construção de dados e do tempo de resposta de curto-prazo tipicamente demandados. Contudo, a aplicação de determinados conceitos e ferramentas pode iluminar a dinâmica social envolvida nos processos de mudança, permitindo uma compreensão mais profunda da agência de humanos e não humanos e de suas associações nas tentativas de "organizar" nas organizações formais. Essa aplicação poderia ser levada a efeito por profissionais das equipes do projeto de mudança das empresas ou por consultorias para suporte que dominassem os conceitos da ANT e da referida metodologia, em especial a cartografia de controvérsias. Controvérsias seriam mais bem compreendidas, subsidiando os processos decisórios.

Todavia, quer nos parecer mais importante aos gestores cultivar um novo entendimento sobre a constituição das chamadas "organizações formais" e do "ambiente em que se inserem", de forma a reduzir sentimentos de onipotência, vindos de (líquidas) certezas de "chegar ao planejado", procurando adotar uma postura de observação criativa e contínua para lidar com os processos "sem dono" (unowned) (MACKAY e CHIA, 2013) que as constituem. 


\section{REFERÊNCIAS}

ALCADIPANI, R.; HASSARD, J. Actor network theory (and after) and critical management studies: contributions to the politics of organising. In: Encontro da ANPAD, 33., 2009, São Paulo. Anais... São Paulo: ANPAD, 2009.

ALCADIPANI, R.; TURETA, C. Teoria ator-rede e análise organizacional: contribuições e possibilidades de pesquisa no Brasil. Organizações \& Sociedade, v. 16, n. 51, p. 647-664, 2009.

ANGROSINO, M. Etnografia e observação participante. Porto Alegre: Artmed, 2009.

ARMENAKIS, A.; BEDEIAN, A. Organizational change: a review of theory and research in the 1990s. Journal of Management, v. 25, n. 3, p. 293-315, 1999.

BARBOUR, R. Grupos focais. Porto Alegre: Artmed, 2009.

BENGTSSON, F.; GERFALK, P. J. Information technology as a change actant in sustainability innovation: Insights from Uppsala. Journal of Strategic Information Systems, v. 20, n. 1, p. 96-112, 2011.

BERGERON, B. Essentials of shared services. New Jersey, NJ: John Wiley \& Sons, 2003.

BURNES, B. Complexity theories and organizational change. International Journal of Management Reviews, v. 7, n. 2, p. 73-90, 2005.

CALLON, M. Some elements of a sociology of translation: domestication of the scallops and the fishermen of St. Brieuc Bay. In: LAW, J. (Ed.). Power, action and belief: a new sociology of knowledge? London: Routledge \& Kegan Paul, 1986. 196-233 p.

CHIA, R. A 'rhizomic' model of organizational change and transformation: perspective from a metaphysics of change. British Journal of Management, v. 10, p. 209-227, 1999.

CHIA, R. Reflections: in praise of silent transformation - allowing change through 'letting happen'. Journal of Change Management, v. 14, n. 1, p. 8-27, 2014.

COTTON, M. Structure, agency and post-Fukushima nuclear policy: an alliance-context-actantiality model of political change. Journal of Risk Research, v. 18, n. 3, p. 317-332, 2014.

CRESWELL, J. Projeto de pesquisa. Porto Alegre: Artmed, 2007.

CZARNIAWSKA, B. A Theory of organizing. Cheltenham: Edward Elgar, 2008.

CZARNIAWSKA, B. Going back to go forward: on studying organizing in action nets. In: HERNES, T.; MAITLIS, S. (Eds.). Process, sensemaking \& organizing. London: Oxford University Press, 2012. 140-160 p.

CZARNIAWSKA, B.; HERNES, T. (Eds.). Actor-network theory and organizing. Herndon, VA: Copenhagen Business School Press, 2005.

DENZIN, N. K.; LINCOLN, Y. S. Introdução: a disciplina e a prática da pesquisa qualitativa. In: DENZIN, N. K.; LINCOLN, Y. S. O planejamento da pesquisa qualitativa: teorias e abordagens. 2. ed. Porto Alegre: Artmed, 2006. 15-47 p.
ELLIS, C.; ADAMS, T.; BOCHNER, A. Autoethnography: an overview. Forum: Qualitative Social Research, v. 12, n. 1, art. 10, 2011.

FRANCISCO, E. R. RAE-Eletrônica: exploração do acervo à luz da bibliometria, geoanálise e redes sociais. RAE, v. 51, n. 3, p. 280306, 2011.

GRAETZ, F.; SMITH, A. Managing organizational change: a philosophies of change approach. Journal of Change Management, $v$. 10, n. 2, p. 135-154, 2010.

GREENWOOD II, R.; HININGS, C. R. Understanding radical organizational change: bringing together the old and the new institutionalism. Academy of Management Review, v. 21, n. 4, p. 1022-1054, 1996.

GREY, C. O fetiche da mudança. RAE, v. 22, n. 1, p. 10-25, 2004.

HARAWAY, D. J. Simians, cyborgs, and women. New York: Routledge, 1991.

HARAWAY, D. J.; KUNZRU, H.; TADEU, T. (Org.). Antropologia do ciborgue: as vertigens do pós-humano. Belo Horizonte: Autêntica, 2009.

HARMAN, G. Prince of networks: Bruno Latour and metaphysics. Melbourne: Re.Press, 2009.

HERNES, T. Actor-network theory, Callon's scallops, and process-based organization studies. In: HERNES, T.; MAITLIS, S. (Eds.). Process, sensemaking \& organizing. London: Oxford University Press, 2012. 161-184 p.

HERNES, T.; MAITLIS, S. Process, sensemaking and organizing: an introduction. In: HERNES, T.; MAITLIS, S. Perspectives on process organization studies. v. 1. London: Oxford University Press, 2012. 27-37 p.

JAIME, P. Pesquisa em organizações: por uma abordagem etnográfica. Civitas, v. 3, n. 2, p. 437-456, 2009.

LANCIONE, M.; CLEGG, S. The chronotopes of change: actor-networks in a changing business school. Journal of Change Management, v. 13, n. 2, p. 117-142, 2013.

LANGLEY, A.; TSOUKAS, H. Introducing "perspectives on process organization studies". In: HERNES, T.; MAITLIS, S. (Eds.). Process, sensemaking \& organizing. London: Oxford University Press, 2012. 1-26 p.

LANGLEY, A. et al. Process studies of change in organization and management: unveiling temporality, activity and flow. Academy of Management Journal, v. 56, n. 1, p. 1-13, 2013.

LANGSTRAND, J.; ELG, M. Non-human resistance in changes towards lean. Journal of Organizational Change Management, v. 25, n. 6, p. 853-866, 2012.

LATOUR, B. The power of association. In: LAW, J. (Ed.). Power, action and belief. London: Routledge \& Kegan Paul, 1986. 264-277 p.

LATOUR, B. The pasteurization of France. Cambridge, MA: Harvard University Press, 1993. 
LATOUR, B. Jamais fomos modernos. Rio de Janeiro: Ed. 34, 1994.

LATOUR, B. Ciência em ação: como seguir cientistas e engenheiros sociedade afora. São Paulo: Ed. Unesp, 2000.

LATOUR, B. A esperança de Pandora: ensaios sobre a realidade dos estudos científicos. Bauru, SP: Edusc, 2001.

LATOUR, B. Reassembling the social: an introduction to actor-network-theory. New York: Oxford University Press, 2005.

LAW, J. On the methods of long-distance control: vessels, navigation and the Portuguese route to India. In: LAW, J. (Ed.). Power, action and belief: a new sociology of Knowledge? London: Routledge \& Kegan Paul, 1986. 234-263 p.

LAW, J. Notes on the theory of the actor network: ordering, strategy and heterogeneity. 1992. Disponível em: <http://faculty. georgetown.edu/irvinem/theory/Law-Notes-on-ANT.pdf $>$. Acesso em: 19 jul. 2011.

LAW, J. Organizing modernity. Oxford: Blackwell Publishers, 1994.

LAW, J. The manager and his powers. Lancaster, 1997. Disponível em: <http://www.lancaster.ac.uk/sociology/research/publications/ papers/law-manager-and-his-powers.pdf>. Acesso em 14/jan/ 2014.

LAW, J. After method: mess in social science research. London: Routledge, 2004.

LAW, J.; SINGLETON, V. Object lessons. Organization, v. 12, n. 3, p. 331-355, 2005.

LAW, J. Actor network theory and material semiotics. 2007. Disponível em: <http://heterogeneities.net/publications/ Law2007ANTandMaterialSemiotics.pdf>. Acesso em: 27 nov. 2015.

MACAULAY, K. D.; YUE, A. R.; THURLOW, A. B. Ghosts in the hallways: unseen actors and organizational change. Journal of Change Management, v. 10, n. 4, p. 335-346, 2010.

MACKAY, R. B.; CHIA, R. Choice, chance, and unintended consequences in strategic change: a process understanding of the rise and fall of NorthCo Automotive. Academy of Management Journal, v. 56, n. 1, p. 208-230, 2013.

MITEV, N. In and out of actor-network theory: a necessary but insufficient journey. Information Technology \& People, v. 22, n. 1, p. 9-25, 2009.

NIKOLOVA, N. Actor-network theory. 2010. Disponível em: <http:// www.sage-ereference.com/organization/Article_n9.html>. Acesso em: 20 mar. 2011.

NOBRE, J. C. A.; PEDRO, R. M. L. R. Reflexões sobre possibilidades metodológicas da Teoria Ator-Rede. Cadernos UniFOA, n. 14, p. 47-56, 2010.

ORLIKOWSKI, W. Improvising organizational transformation over time: a situated change perspective. Information Systems Research, v. 7, n. 1, p. 63-92, 1996.

PETTIGREW, A. M. The awakening giant: continuity and change in Imperial Chemical Industries. Oxford: Basil Blackwell, 1985.

PETTIGREW, A. M. Longitudinal field research on change: theory and practice. Organization Science, v. 1, n. 3, p. 267-292, 1990.
PETTIGREW, A. M. Context and action in the transformation of the firm: a reprise. Journal of Management Studies, v. 49, n. 7, p. 1304-1328, 2012.

PETTIGREW, A. M.; WOODMAN, R.; CAMERON, K. Studying organizational change and development: challenges for future research. Academy of Management Journal, v. 44, n. 4, p. 697-713, 2001.

POLLACK, J.; COSTELLO, K.; SANKARAN, S. Applying actor-network theory as a sensemaking framework for complex organisational change programs. International Journal of Project Management, v. 31, n. 8, p. 1118-1128, 2013.

POOLE, M. S.; VAN DE VEN. A. H. Handbook of organizational change and innovation. New York: Oxford University Press, 2004.

QUINN, B.; COOKE, R.; KRIS, A. Shared services. London: Prentice Hall, 2000.

REED-DANAHAY, D. E. (Eds.). Auto/ethnography. Oxford/ Washington: Berg, 1997.

ROMANELLI, E.; TUSHMAN, M. L. Organizational transformation as punctuated equilibrium: an empirical test. Academy of Management Journal, v. 37, n. 5, p. 1141-1166, 1994.

SCHULMAN, D. et al. Shared services: adding value to the business units. New York: John Wiley \& Sons, 1999.

SCHWAB, K. Dominando os novos desafios da vida moderna. Disponível em: <http://www.estadao.com.br/noticias/impresso,dominando-os-novos-desafios-da-vida-moderna,756496,0.htm>. Acesso em: 20 ago. 2011.

STAKE, R. E. Qualitative case studies. In: DENZIN, N. K.; LINCOLN, Y. S. (Eds.). The Sage handbook of qualitative research. 3. ed. Thousand Oaks, CA: Sage, 2005. 443-466 p.

TSOUKAS, H.; CHIA, R. On organizational becoming: rethinking organizational change. Organization Science, v. 13, n. 5, p. 567582, 2002.

TURETA, C.; ALCADIPANI, R. Entre o observador e o integrante da escola de samba: os não-humanos e as transformações durante uma pesquisa de campo. RAC, v. 15, n. 2, p. 209-227, 2011.

TUSHMAN, M. L.; ROMANELLI, E. Organizational evolution: a methamorphosis model of convergence and reorientation. Research in Organizational Behavior, v. 7, p. 171-222, 1985.

VAN de VEN, A. H.; POOLE, M. S. Explaining development and change in organizations. The Academy of Management Review, v. 20, n. 3, p. 510-540, 1995.

VAN de VEN, A. H.; POOLE, M. S. Alternative approaches for studying organizational change. Organization Studies, v. 26, n. 9, p. 1377-1404, 2005.

VELHO, L.; VELHO, P. A controvérsia sobre o uso de alimentação 'alternativa' no combate à subnutrição no Brasil. História, Ciências, Saúde, v. 9, n. 1, p. 125-157, 2002.

VENTURINI, T. Diving in magma: how to explore controversies with actor-network theory. Public Understanding of Science, v. 19 , n. 3, p. 258-273, 2010a. 
VENTURINI, T. Building on faults: how to represent controversies with digital methods. 2010b. Disponível em: <http://www.medialab.sciences-po.fr/publications/Venturini-Building_on_Faults.pdf>. Acesso em: 10 fev. 2012.

WEICK, K. The social psychology of organizing. 2. ed. Reading, MA: Addison-Wesley, 1979.
WEICK, K.; QUINN, R. Organizational change and development. Annual Review of Psychology, v. 50, p. 361-386, 1999.

WETZEL, R.; VAN GORP, L. Eighteen shades of grey? An explorative literature review into the theoretical flavours of organizational change research. Journal of Organizational Change Management, v. 27, n. 1, p. 115-146, 2014.

Clovis Cerretto

Doutor em Administração de Empresas pela Universidade Presbiteriana Mackenzie.E-mail: cloviscerretto@uol.com.br. 